Cochrane Database of Systematic Reviews

\title{
Skin preparation for preventing infection following caesarean section (Review)
}

Hadiati DR, Hakimi M, Nurdiati DS, da Silva Lopes K, Ota E

Hadiati DR, Hakimi M, Nurdiati DS, da Silva Lopes K, Ota E.

Skin preparation for preventing infection following caesarean section.

Cochrane Database of Systematic Reviews 2018, Issue 10. Art. No.: CD007462.

DOI: 10.1002/14651858.CD007462.pub4.

www.cochranelibrary.com 
TABLE OF CONTENTS

HEADER 1

ABSTRACT

PLAIN LANGUAGE SUMMARY

SUMMARY OF FINDINGS

BACKGROUND

OBJECTIVES

METHODS

RESULTS

Figure 1.

Figure 2.

Figure 3.

DISCUSSION

AUTHORS' CONCLUSIONS

ACKNOWLEDGEMENTS

REFERENCES

CHARACTERISTICS OF STUDIES

DATA AND ANALYSES

Analysis 1.1. Comparison 1 Drape versus no drape, Outcome 1 Surgical site infection.

Analysis 1.2. Comparison 1 Drape versus no drape, Outcome 2 Length of stay.

Analysis 2.1. Comparison 2 One-minute alcohol scrub with iodophor drape versus five-minute iodophor scrub without drape, Outcome 1 Surgical site infection.

Analysis 2.2. Comparison 2 One-minute alcohol scrub with iodophor drape versus five-minute iodophor scrub without drape, Outcome 2 Endomyometritis.

Analysis 2.3. Comparison 2 One-minute alcohol scrub with iodophor drape versus five-minute iodophor scrub without drape, Outcome 3 Reduction of skin bacteria colony counts.

Analysis 3.1. Comparison 3 Parachlorometaxylenol with iodine versus iodine alone, Outcome 1 Surgical site infection. .......... Analysis 3.2. Comparison 3 Parachlorometaxylenol with iodine versus iodine alone, Outcome 2 Endometritis. ....................... Analysis 4.1. Comparison 4 Chlorhexidine gluconate versus povidone iodine, Outcome 1 Surgical site infection.

Analysis 4.2. Comparison 4 Chlorhexidine gluconate versus povidone iodine, Outcome 2 Endometritis.

Analysis 4.3. Comparison 4 Chlorhexidine gluconate versus povidone iodine, Outcome 3 Re-admission resulting from infection.

Analysis 4.4. Comparison 4 Chlorhexidine gluconate versus povidone iodine, Outcome 4 Bacterial growth 18 hours.

Analysis 4.5. Comparison 4 Chlorhexidine gluconate versus povidone iodine, Outcome 5 Adverse events (maternal). APPENDICES

WHAT'S NEW

HISTORY

CONTRIBUTIONS OF AUTHORS

DECLARATIONS OF INTEREST

SOURCES OF SUPPORT

DIFFERENCES BETWEEN PROTOCOL AND REVIEW

INDEX TERMS 
[Intervention Review]

\section{Skin preparation for preventing infection following caesarean section}

Diah R Hadiati ${ }^{1}$, Mohammad Hakimi ${ }^{1}$, Detty S Nurdiati² ${ }^{2}$ Katharina da Silva Lopes ${ }^{3}$, Erika Ota ${ }^{3}$

1Faculty of Medicine, Public Health and Nursing, Universitas Gadjah Mada, Yogyakarta, Indonesia. 2Department of Obstetrics and Gynaecology, Faculty of Medicine, Universitas Gadjah Mada, Yogyakarta, Indonesia. ${ }^{3}$ Global Health Nursing, Graduate School of Nursing Sciences, St. Luke's International University, Tokyo, Japan

Contact address: Diah R Hadiati, Faculty of Medicine, Public Health and Nursing, Universitas Gadjah Mada, DR.Sardjito Hospital, Jl. Kesehatan No.1, Sekip, Yogyakarta, Daerah Istimewa Yogyakarta, 55281, Indonesia. rumekti@yahoo.com.

Editorial group: Cochrane Pregnancy and Childbirth Group.

Publication status and date: New search for studies and content updated (no change to conclusions), published in Issue 10, 2018.

Citation: Hadiati DR, Hakimi M, Nurdiati DS, da Silva Lopes K, Ota E. Skin preparation for preventing infection following caesarean section. Cochrane Database of Systematic Reviews 2018, Issue 10. Art. No.: CD007462. DOI: 10.1002/14651858.CD007462.pub4.

Copyright @ 2018 The Cochrane Collaboration. Published by John Wiley \& Sons, Ltd.

\section{A B S T R A C T}

\section{Background}

The risk of maternal mortality and morbidity (particularly postoperative infection) is higher for caesarean section (CS) than for vaginal birth. With the increasing rate of CS, it is important to minimise the risks to the mother as much as possible. This review focused on different forms and methods of preoperative skin preparation to prevent infection. This review is an update of a review that was first published in 2012, and updated in 2014.

\section{Objectives}

To compare the effects of different antiseptic agents, different methods of application, or different forms of antiseptic used for preoperative skin preparation for preventing postcaesarean infection.

\section{Search methods}

For this update, we searched Cochrane Pregnancy and Childbirth's Trials Register, ClinicalTrials.gov, the WHO International Clinical Trials Registry Platform (ICTRP) (27 November 2017), and reference lists of retrieved studies.

\section{Selection criteria}

Randomised and quasi-randomised trials, evaluating any type of preoperative skin preparation agents, forms, and methods of application for caesarean section.

Comparisons of interest in this review were between different antiseptic agents used for CS skin preparation (e.g. alcohol, povidone iodine), different methods of antiseptic application (e.g. scrub, paint, drape), different forms of antiseptic (e.g. powder, liquid), and also between different skin preparations, such as a plastic incisional drape, which may or may not be impregnated with antiseptic agents.

Only studies involving the preparation of the incision area were included. This review did not cover studies of preoperative handwashing by the surgical team or preoperative bathing.

\section{Data collection and analysis}

Three review authors independently assessed all potential studies for inclusion, assessed risk of bias, and extracted the data using a predesigned form. We checked data for accuracy. We assessed the quality of the evidence using the GRADE approach. 


\section{Main results}

For this update, we included 11 randomised controlled trials (RCTs), with a total of 6237 women who were undergoing CS. Ten trials (6215 women) contributed data to this review. All included studies were individual RCTs. We did not identify any quasi- or cluster-RCTs. The trial dates ranged from 1983 to 2016. Six trials were conducted in the USA, and the remainder in Nigeria, South Africa, France, Denmark, and Indonesia.

The included studies were broadly methodologically sound, but raised some specific concerns regarding risk of bias in a number of cases.

\section{Drape versus no drape}

This comparison investigated the use of a non-impregnated drape versus no drape, following preparation of the skin with antiseptics. For women undergoing CS, low-quality evidence suggested that using a drape before surgery compared with no drape, may make little or no difference to the incidence of surgical site infection (risk ratio (RR) 1.29, 95\% confidence interval (CI) 0.97 to $1.71 ; 2$ trials, 1294 women), or length of stay in the hospital (mean difference (MD) 0.10 day, $95 \% \mathrm{Cl}-0.27$ to 0.461 trial, 603 women).

\section{One-minute alcohol scrub with iodophor drape versus five-minute iodophor scrub without drape}

One trial compared an alcohol scrub and iodophor drape with a five-minute iodophor scrub only, and reported no surgical site infection in either group ( 79 women, very-low quality evidence). We were uncertain whether the combination of a one-minute alcohol scrub and a drape reduced the incidence of endomyometritis when compared with a five-minute scrub, because the quality of the evidence was very low (RR $1.62,95 \% \mathrm{Cl} 0.29$ to 9.16 ; 1 trial, 79 women).

\section{Parachlorometaxylenol with iodine versus iodine alone}

We were uncertain whether parachlorometaxylenol with iodine before CS made any difference to the incidence of surgical site infection (RR 0.33, 95\% Cl 0.04 to 2.99; 1 trial, 50 women), or endometritis (RR 0.88, 95\% Cl 0.56 to $1.38 ; 1$ trial, 50 women) when compared with iodine alone, because the quality of the evidence was very low.

\section{Chlorhexidine gluconate versus povidone iodine}

Low-quality evidence suggested that chlorhexidine gluconate before CS, when compared with povidone iodine, may make little or no difference to the incidence of surgical site infection (RR $0.80,95 \% \mathrm{Cl} 0.62$ to 1.02; 6 trials, 3607 women). However, surgical site infection appeared to be slightly reduced for women for whom chlorhexidine gluconate was used compared with povidone iodine after we removed four trials at high risk of bias for outcome assessment, in a sensitivity analysis (RR 0.59, 95\% $\mathrm{Cl} 0.37$ to $0.95 ; 2$ trials, 1321 women).

Low-quality evidence indicated that chlorhexidine gluconate before CS, when compared with povidone iodine, may make little or no difference to the incidence of endometritis (RR 1.01,95\% Cl 0.51 to $2.01 ; 2$ trials, 2079 women), or to reducing maternal skin irritation or allergic skin reaction ( $\mathrm{RR} 0.60,95 \% \mathrm{Cl} 0.22$ to $1.63 ; 2$ trials, 1521 women).

One small study (60 women) reported reduced bacterial growth at 18 hours after CS for women who had chlorhexidine gluconate preparation compared with women who had povidone iodine preparation ( $\mathrm{RR} 0.23,95 \% \mathrm{Cl} 0.07$ to 0.70 ).

None of the included trials reported on maternal mortality or repeat surgery.

\section{Chlorhexidine $\mathbf{0 . 5} \%$ versus $70 \%$ alcohol plus drape}

One trial, which was only available as an abstract, investigated the effect of skin preparation on neonatal adverse events, and found cord blood iodine concentration to be higher in the iodine group.

\section{Authors' conclusions}

There was insufficient evidence available from the included RCTs to fully evaluate different agents and methods of skin preparation for preventing infection following caesarean section. Therefore, it is not yet clear what sort of skin preparation may be most effective for preventing postcaesarean surgical site infection, or for reducing other undesirable outcomes for mother and baby.

Most of the evidence in this review was deemed to be very low or low quality. This means that for most findings, our confidence in any evidence of an intervention effect is limited, and indicates the need for more high-quality research.

This field needs high quality, well designed RCTs, with larger sample sizes. High priority questions include comparing types of antiseptic (especially iodine versus chlorhexidine), and application methods (scrubbing, swabbing, or draping). We found four studies that were ongoing; we will incorporate the results of these studies in future updates of this review.

\section{PLAIN LANGUAGE SUMMARY}

\section{Skin preparation for preventing infection following caesarean section}


This review is an update of a review that was first published in 2012, and updated in 2014.

\section{What is the issue?}

The aim of this Cochrane Review was to find out what methods of skin preparation before caesarean section were most effective in preventing infection after the operation. We collected and analysed all studies that assessed the effectiveness of antiseptics used to prepare the skin before making an incision (or cut) for the caesarean section. We only included analysis of preparations that were used to prepare the surgical site on the abdomen before caesarean section; we did not look at handwashing by the surgical team, or bathing the mother.

\section{Why is this important?}

Infections of surgical incisions are the third most frequently reported hospital-acquired infections. Women who give birth by caesarean section are exposed to infection from germs already present on the mother's own skin, or from external sources. The risk of infection following a caesarean section can be 10 times that of vaginal birth. Therefore, preventing infection by properly preparing the skin before the incision is made is an important part of the overall care given to women prior to caesarean birth. An antiseptic is a substance applied to remove bacteria that can cause harm to the mother or baby when they multiply. Antiseptics include iodine or povidone iodine, alcohol, chlorhexidine, and parachlorometaxylenol. They can be applied as liquids or powders, scrubs, paints, swabs, or on impregnated 'drapes' that stick to the skin, which the surgeon then cuts through. Non-impregnated drapes can also be applied, once the skin has been scrubbed or swapped, with the aim of reducing the spread of any remaining bacteria during surgery. It is important to know if some of these antiseptics or methods work better than others.

\section{What evidence did we find?}

This updated review included 11 trials with 6237 women. Six trials were conducted in the United States; the remaining trials were in Nigeria, South Africa, France, Denmark, and Indonesia. The review looked at what was best for women and babies when it came to important outcomes including: infection of the site where the surgeon cut the woman to perform the caesarean section; inflammation of the lining of the womb (metritis and endometritis); how long the woman stayed in hospital; and any other adverse effects, such as irritation of the woman's skin, or any reported impact on the baby. Not all of the 11 trials explored all of these outcomes, and the evidence for each outcome was usually based on results from far fewer than 6237 women.

Much of the evidence we found was of relatively poor quality, due to limits in the ways that the studies were conducted. This means that we could not be certain about most of the findings, even when we combined the results from a number of different studies. The evidence suggested that there was probably little or no difference between the various antiseptics in the incidence of surgical site infection, endometritis, skin irritation, or allergic skin reaction in the mother. However, in one study, there was a reduction in bacterial growth on the skin at 18 hours after caesarean section for women who received a skin preparation with chlorhexidine gluconate compared with women who received the skin preparation with povidone iodine, but more data are needed to see if this actually reduces infections for women.

\section{What does this mean?}

The available evidence from the trials that have been conducted was insufficient to tell us the best type of skin preparation for preventing surgical site infection following caesarean section. More high-quality research is needed. We found four studies that were still ongoing. We will incorporate the results of these studies into this review in future updates. 
SUMMARY OF FINDINGS

\section{Summary of findings for the main comparison. Drape compared to no drape before caesarean section for preventing infection}

Drape compared to no drape

Population: women undergoing caesarean section

Settings: hospitals in Denmark (8 trials), and South Africa (1 trial)

Intervention: antiseptic application using drape

Comparison: no drape

\begin{tabular}{|c|c|c|c|c|c|c|}
\hline \multirow[t]{2}{*}{ Outcomes } & \multicolumn{2}{|c|}{ Anticipated absolute effects ${ }^{\star}(95 \% \mathrm{Cl})$} & \multirow{2}{*}{$\begin{array}{l}\text { Relative ef- } \\
\text { fect } \\
(95 \% \mathrm{CI})\end{array}$} & \multirow{2}{*}{$\begin{array}{l}\text { No of partici- } \\
\text { pants } \\
\text { (studies) }\end{array}$} & \multirow{2}{*}{$\begin{array}{l}\text { Quality of the } \\
\text { evidence } \\
\text { (GRADE) }\end{array}$} & \multirow[t]{2}{*}{ Comments } \\
\hline & Risk with no drape & Risk with drape & & & & \\
\hline Surgical site infection & 112 per 1000 & $\begin{array}{l}144 \text { per } 1000 \\
(109 \text { to } 191)\end{array}$ & $\begin{array}{l}\text { RR } 1.29 \\
\text { (0.97 to } 1.71 \text { ) }\end{array}$ & $\begin{array}{l}1294 \\
\text { (2 RCTs) }\end{array}$ & $\begin{array}{l}\oplus \oplus \Theta \Theta \\
\text { LOW a,b }\end{array}$ & \\
\hline Length of stay (days) & $\begin{array}{l}\text { The mean length of stay } \\
\text { with no drape was } 5.7 \\
\text { days }\end{array}$ & $\begin{array}{l}\text { The mean number of days } \\
\text { with a drape was } 0.1 \text { high- } \\
\text { er } \\
\text { ( } 0.27 \text { days lower to } 0.46 \\
\text { days higher) }\end{array}$ & - & $\begin{array}{l}603 \\
(1 \mathrm{RCT})\end{array}$ & $\begin{array}{l}\oplus \oplus \oplus \ominus \\
\text { MODERATE } b\end{array}$ & \\
\hline
\end{tabular}

${ }^{\star}$ The risk in the intervention group (and its $95 \%$ confidence interval) is based on the assumed risk in the comparison group and the relative effect of the intervention (and its $95 \% \mathrm{Cl}$ ).

Cl: Confidence interval; RR: Risk ratio;

\section{GRADE Working Group grades of evidence}

High quality: We are very confident that the true effect lies close to that of the estimate of the effect

Moderate quality: We are moderately confident in the effect estimate: The true effect is likely to be close to the estimate of the effect, but there is a possibility that it is substantially different 
a Selection bias was unclear and blinding of outcome assessor was at high risk of bias (risk of bias -1)

$b$ Wide $95 \% \mathrm{Cl}$ (imprecision -1)

Summary of findings 2. One-minute alcohol scrub with iodophor drape compared to five-minute iodophor scrub without drape for preventing infection following caesarean section

One-minute alcohol scrub with iodophor drape compared to five-minute iodophor scrub without drape

Population: women undergoing caesarean section

Settings: a university hospital in the USA

Intervention: one-minute alcohol scrub with iodophor drape

Comparison: five-minute iodophor scrub without drape

\begin{tabular}{|c|c|c|c|c|c|c|}
\hline \multirow[t]{2}{*}{ Outcomes } & \multicolumn{2}{|c|}{ Anticipated absolute effects* $(95 \% \mathrm{Cl})$} & \multirow{2}{*}{$\begin{array}{l}\text { Relative ef- } \\
\text { fect } \\
(95 \% \mathrm{CI})\end{array}$} & \multirow{2}{*}{$\begin{array}{l}\text { No of partici- } \\
\text { pants } \\
\text { (studies) }\end{array}$} & \multirow{2}{*}{$\begin{array}{l}\text { Quality of the } \\
\text { evidence } \\
\text { (GRADE) }\end{array}$} & \multirow[t]{2}{*}{ Comments } \\
\hline & $\begin{array}{l}\text { Risk with 5-minute } \\
\text { iodophor scrub with- } \\
\text { out drape }\end{array}$ & $\begin{array}{l}\text { Risk with 1-minute alcohol } \\
\text { scrub with iodophor drape }\end{array}$ & & & & \\
\hline \multirow{2}{*}{$\begin{array}{l}\text { Surgical site infec- } \\
\text { tion }\end{array}$} & Study population & & \multirow[t]{2}{*}{ not estimable } & \multirow{2}{*}{$\begin{array}{l}79 \\
(1 \mathrm{RCT})\end{array}$} & \multirow{2}{*}{$\begin{array}{l}\oplus \odot \odot \odot \\
\text { VERY LOW a,b }\end{array}$} & \multirow{2}{*}{$\begin{array}{l}\text { There were no surgical site infec- } \\
\text { tions in either group. }\end{array}$} \\
\hline & 0 per 1000 & $\begin{array}{l}0 \text { per } 1000 \\
(0 \text { to } 0)\end{array}$ & & & & \\
\hline \multirow[t]{2}{*}{ Endomyometritis } & \multicolumn{2}{|l|}{ Study population } & \multirow{2}{*}{$\begin{array}{l}\text { RR } 1.62 \\
(0.29 \text { to } 9.16)\end{array}$} & \multirow{2}{*}{$\begin{array}{l}79 \\
(1 \mathrm{RCT})\end{array}$} & \multirow{2}{*}{$\begin{array}{l}\oplus \odot \Theta \odot \\
\text { VERY LOW a,c }\end{array}$} & \\
\hline & 49 per 1000 & $\begin{array}{l}79 \text { per } 1000 \\
(14 \text { to } 447)\end{array}$ & & & & \\
\hline Length of stay & - & - & - & - & - & $\begin{array}{l}\text { This outcome was not reported in } \\
\text { the included study. }\end{array}$ \\
\hline
\end{tabular}

${ }^{*}$ The risk in the intervention group (and its $95 \%$ confidence interval) is based on the assumed risk in the comparison group and the relative effect of the intervention (and its $95 \% \mathrm{Cl}$ ). 


\section{GRADE Working Group grades of evidence}

High quality: We are very confident that the true effect lies close to that of the estimate of the effect

Moderate quality: We are moderately confident in the effect estimate: The true effect is likely to be close to the estimate of the effect, but there is a possibility that it is substantially different

Low quality: Our confidence in the effect estimate is limited: The true effect may be substantially different from the estimate of the effect

Very low quality: We have very little confidence in the effect estimate: The true effect is likely to be substantially different from the estimate of effect

a Allocation concealment and blinding of outcome assessor was unclear risk of bias (risk of bias -1)

$b$ The number of event was 0 in each group, small sample size (imprecision -2)

c Small sample size with wide $95 \% \mathrm{Cl}$ (imprecision -2 )

\section{Summary of findings 3. Parachlorometaxylenol with iodine versus iodine alone for preventing infection following caesarean section}

\section{Parachlorometaxylenol with iodine versus iodine alone}

Population: women undergoing caesarean section

Settings: a hospital in USA

Intervention: parachlorometaxylenol with iodine

Comparison: iodine alone

\begin{tabular}{|c|c|c|c|c|c|c|}
\hline \multirow[t]{2}{*}{ Outcomes } & \multicolumn{2}{|c|}{ Illustrative comparative risks ${ }^{\star}(95 \% \mathrm{Cl})$} & \multirow{2}{*}{$\begin{array}{l}\text { Relative effect } \\
(95 \% \mathrm{Cl})\end{array}$} & \multirow{2}{*}{$\begin{array}{l}\text { No of partici- } \\
\text { pants } \\
\text { (studies) }\end{array}$} & \multirow{2}{*}{$\begin{array}{l}\text { Quality of the } \\
\text { evidence } \\
\text { (GRADE) }\end{array}$} & \multirow[t]{2}{*}{ Comments } \\
\hline & $\begin{array}{l}\text { Risk with iodine } \\
\text { alone }\end{array}$ & $\begin{array}{l}\text { Risk with } \\
\text { parachlorometaxylenol with } \\
\text { iodine }\end{array}$ & & & & \\
\hline \multirow[t]{2}{*}{ Surgical site infection } & \multicolumn{2}{|l|}{ Study population } & \multirow{2}{*}{$\begin{array}{l}\text { RR } 0.33 \\
\text { (0.04 to 2.99) }\end{array}$} & \multirow{2}{*}{$\begin{array}{l}50 \\
\text { (1 study) }\end{array}$} & \multirow{2}{*}{$\begin{array}{l}\oplus \odot \Theta \odot \\
\text { VERY LOW a,b }\end{array}$} & \\
\hline & 120 per 1000 & $\begin{array}{l}40 \text { per } 1000 \\
(5 \text { to } 359)\end{array}$ & & & & \\
\hline \multirow[t]{2}{*}{ Endometritis } & Study population & & \multirow{2}{*}{$\begin{array}{l}\text { RR } 0.88 \\
\text { (0.56 to } 1.38)\end{array}$} & \multirow{2}{*}{$\begin{array}{l}50 \\
\text { (1 study) }\end{array}$} & \multirow{2}{*}{$\begin{array}{l}\oplus \Theta \Theta \Theta \\
\text { VERY LOW a,b }\end{array}$} & \\
\hline & 640 per 1000 & $\begin{array}{l}563 \text { per } 1000 \\
\text { (358 to } 883 \text { ) }\end{array}$ & & & & \\
\hline Length of stay & - & - & - & - & - & $\begin{array}{l}\text { This outcome was not re- } \\
\text { ported in the included } \\
\text { study. }\end{array}$ \\
\hline
\end{tabular}


${ }^{*}$ The basis for the assumed risk (e.g. the median control group risk across studies) is provided in footnotes. The corresponding risk (and its $95 \%$ confidence interval) is based on the assumed risk in the comparison group and the relative effect of the intervention (and its $95 \% \mathrm{Cl}$ ).

Cl: Confidence interval; RR: Risk ratio;

GRADE Working Group grades of evidence

High quality: Further research is very unlikely to change our confidence in the estimate of effect.

Moderate quality: Further research is likely to have an important impact on our confidence in the estimate of effect and may change the estimate.

Low quality: Further research is very likely to have an important impact on our confidence in the estimate of effect and is likely to change the estimate.

Very low quality: We are very uncertain about the estimate.

a Wide confidence interval crossing the line of no effect and small sample size (imprecision -2)

$b$ Blinding of outcome assessor was at high risk of bias (risk of bias -1 ).

\section{Summary of findings 4. Chlorhexidine gluconate compared to povidone iodine for preventing infection following caesarean section}

Chlorhexidine gluconate compared to povidone iodine

Population: women undergoing caesarean section

Settings: single-centre or multicenter trials in Nigeria, USA, and Indonesia

Intervention: chlorhexidine gluconate

Comparison: povidone iodine

\begin{tabular}{|c|c|c|c|c|c|}
\hline \multirow[t]{2}{*}{ Outcomes } & \multicolumn{2}{|c|}{ Anticipated absolute effects ${ }^{*}(95 \% \mathrm{Cl})$} & \multirow{2}{*}{$\begin{array}{l}\text { Relative effect } \\
(95 \% \mathrm{Cl})\end{array}$} & \multirow{2}{*}{$\begin{array}{l}\text { No of partici- } \\
\text { pants } \\
\text { (studies) }\end{array}$} & \multirow{2}{*}{$\begin{array}{l}\text { Quality of the CoI } \\
\text { evidence } \\
\text { (GRADE) }\end{array}$} \\
\hline & $\begin{array}{l}\text { Risk with povidone } \\
\text { iodine }\end{array}$ & $\begin{array}{l}\text { Risk with chlorhexidine } \\
\text { gluconate }\end{array}$ & & & \\
\hline \multirow[t]{2}{*}{ Surgical site infection } & \multicolumn{2}{|l|}{ Study population } & \multirow{2}{*}{$\begin{array}{l}\text { RR } 0.80 \\
\text { (0.62 to } 1.02 \text { ) }\end{array}$} & \multirow{2}{*}{$\begin{array}{l}3607 \\
\text { (6 RCTs) }\end{array}$} & \multirow{2}{*}{$\begin{array}{l}\oplus \oplus \ominus \ominus \\
\text { LOW a,b }\end{array}$} \\
\hline & 70 per 1000 & $\begin{array}{l}56 \text { per } 1000 \\
\text { (44 to } 72 \text { ) }\end{array}$ & & & \\
\hline \multirow[t]{2}{*}{ Endometritis } & Study population & & \multirow{2}{*}{$\begin{array}{l}\text { RR } 1.01 \\
\text { (0.51 to } 2.01 \text { ) }\end{array}$} & \multirow{2}{*}{$\begin{array}{l}2079 \\
\text { (2 RCTs) }\end{array}$} & \multirow{2}{*}{$\begin{array}{l}\oplus \oplus \odot \ominus \\
\text { LOW a,b }\end{array}$} \\
\hline & 15 per 1000 & $\begin{array}{l}15 \text { per } 1000 \\
\text { ( } 8 \text { to } 31)\end{array}$ & & & \\
\hline
\end{tabular}




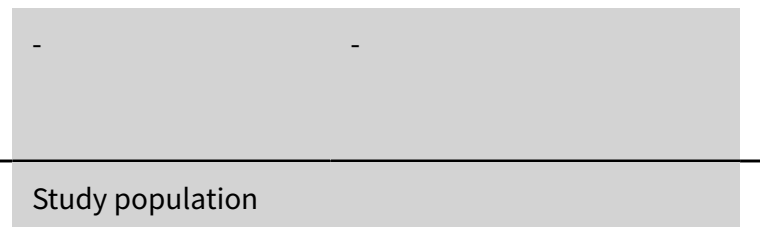

$\begin{array}{ll}- & \text { This outcome was not re- } \\ \text { ported in any of the includ- } \\ \text { ed studies. }\end{array}$

Adverse events (mater-

nal) - skin irritation or al-

lergic skin reaction

RR 0.60

(0.22 to 1.63$)$

1521

$\oplus \oplus \ominus \ominus$

ed studies.

'The risk in the intervention group (and its 95\% confidence interval) is based on the assumed risk in the comparison group and the relative effect of the intervention (and its $95 \% \mathrm{Cl}$ ).

Cl: Confidence interval; RR: Risk ratio;

\section{GRADE Working Group grades of evidence}

High quality: We are very confident that the true effect lies close to that of the estimate of the effect

Moderate quality: We are moderately confident in the effect estimate: The true effect is likely to be close to the estimate of the effect, but there is a possibility that it is substantially different

Low quality: Our confidence in the effect estimate is limited: The true effect may be substantially different from the estimate of the effect

Very low quality: We have very little confidence in the effect estimate: The true effect is likely to be substantially different from the estimate of effect

a Wide $95 \% \mathrm{Cl}$ overlapped line of no effect (imprecision -1)

$b$ Selection bias and blinding of outcome assessment was at high risk of bias (risk of bias -1 ) 


\section{B A C K G R O U N D}

\section{Description of the condition}

Caesarean section is an increasingly common major surgical procedure performed on women (WHO 2015). For example, in 2015, every third birth (32\%) in the United States was a caesarean delivery (Martin 2015). The increasing rate of caesarean birth worldwide in both high- and low-income countries, is well established, and a concern to many (Thomas 2001). Between 2004 and 2011, an overall increase of the global rate of caesarean section, of up to $31.2 \%$, was reported (Vogel 2015). The risk of maternal morbidity and mortality is higher in caesarean section than in vaginal birth; postoperative infection is a common component of morbidity. With the increase in caesarean section, it is important that the risks to the mother are minimised as far as possible (Thomas 2001). This review focused on different forms and methods for preoperative skin preparation to prevent infection; it did not include studies of preoperative handwashing of the surgical team and preoperative bathing.

Women who give birth by caesarean section are exposed to both endogenous (internal) and exogenous (external) sources of infection during birth. Exposure to a hospital environment places these women at risk of developing hospital-acquired infections. The rate of postcaesarean infection has been estimated to be 10 times greater than that after vaginal birth (Henderson 1995).

The Centers for Disease Control and Prevention (CDC) estimates that 27 million surgical procedures are performed in the United States each year. The CDC's National Nosocomial Infections Surveillance system reports that surgical site infections are the third most frequently reported nosocomial infection, accounting for $14 \%$ to $16 \%$ of all such infections (CDC 2005). Preventing infection by properly preparing the skin before incision is thus a vital part of the overall care given to women during caesarean birth.

The incidence of abdominal incisional infections following caesarean section ranges from $3 \%$ to $15 \%$. A postcaesarean surgical site infection is a bacterial infection in the surgical incision following an abdominal birth. Women who develop a postcaesarean surgical site infection typically experience a temperature of $38.0^{\circ} \mathrm{C}\left(100.4^{\circ} \mathrm{F}\right)$ or higher and lower abdominal pain (Cunningham 2018). Abdominal incisional abscesses that develop following caesarean birth usually cause fever on about the fourth postoperative day. In many cases, these are preceded by uterine infection, and fever persists from the first or second postoperative day. Wound redness (erythema) and drainage may also be present. Organisms causing these infections are usually the same as those isolated from amniotic fluid at caesarean birth, but hospital-acquired pathogens may also be the cause (Lewis 2013).

Some women are more likely than others to develop a postcaesarean surgical site infection. Women at increased risk include those who are obese; have diabetes or an immunosuppressive disorder (HIV infection); have chorioamnionitis (infection of the amniotic fluid and fetal membrane) during labour; anaemia; or are taking corticosteroids (by mouth or intravenously (Cunningham 2018)).

In addition to surgical site infections, another common source of morbidity is postcaesarean metritis, including endometritis, an infection that develops within the lining of the uterus after birth. Despite the use of routine antibiotics before or during surgery (perioperative prophylaxis), estimates of metritis following caesarean range form $10 \%$ to $20 \%$ (Normand 2001).

\section{Description of the intervention}

Proper preparation of an incision site involves removing surface dirt and oil with a soap or detergent scrub plus applying a topical antimicrobial agent that will reduce the bacterial population to a minimal level. In surgical patients, the choice of surgical scrub and the duration of scrubbing have not been shown to make any significant difference in the rate of surgical site infection in either clean or clean-contaminated wounds (such as caesarean skin incision (Dumville 2015; Mangram 1999)).

Antiseptics to prevent infection have been in use for over 150 years. Antiseptic handwash solution was first introduced by Semmelweis, in 1847 , at the Vienna Maternity Hospital, to reduce maternal mortality due to puerperal sepsis (Loudon 2002). Later, in 1864, Lister introduced carbolic acid spray preparation for the operative site. Since then, many solutions (including alcoholic iodine, mercuric compounds, and ether) have been used to prepare the operative site. However, as another Cochrane review has shown, there is uncertainty about which antiseptic skin preparation is the most effective for preventing postoperative surgical site infections (Dumville 2015).

There are six types of antiseptics that are designed for topical application: iodine or iodophors, alcohol, chlorhexidine gluconate, hexachlorophene, parachlorometaxylenol, and triclosan (Dumville 2015; Larson 1988). For the purpose of this review, antiseptic agents can be applied in the form of liquids, solutions, or powders, or delivered on impregnated drapes.

\section{How the intervention might work}

The removal of transient bacteria and reduction of the number of existing organisms by antiseptic is recommended prior to surgery by several organisations, for example, the Royal College of Surgeons of England (Leaper 2001), the Centers for Disease Control and Prevention (Mangram 1999), and the Association of Operating Room Nurses (AORN 2002). Several antiseptic agents are available for preoperative preparation of skin at the incision site. Leclair 1990 described an antiseptic as 'a chemical agent that reduces the microbial population on the skin'. It is suggested that the ideal agent would kill all bacteria, fungi, viruses, protozoa, tubercle bacilli, and spores; be nontoxic, hypoallergenic, and safe to use in all body regions; not be absorbed; have residual activity, and be safe for repetitive use (Dumville 2015; Hardin 1997).

Antiseptics for preoperative skin preparation should be broadspectrum and fast-acting, and contain an antimicrobial ingredient that results in significant reduction in the number of microorganisms on intact skin (Larson 1988). The primary action of antiseptics includes both the mechanical removal and chemical killing, and the inhibition of both contaminating and colonising flora.

\section{Why it is important to do this review}

There is a Cochrane Review on the use of preoperative skin antiseptics for preventing infections (Dumville 2015). However, although the scope of the Dumville 2015 review included clean and clean-contaminated surgical operations, including caesarean 
section, the focus was solely on preventing surgical site infections. In our review, the focus extended to preventing all types of infection, such as endometritis or metritis. In this review, we did not look at different methods of surgical incision for caesarean, because that was the topic of another Cochrane Review (Mathai 2013).

\section{OB JECTIVES}

To compare the effects of different antiseptic agents, different methods of application, or different forms of antiseptic used for preoperative skin preparation for preventing postcaesarean infection.

\section{METHODS}

\section{Criteria for considering studies for this review}

\section{Types of studies}

All published and unpublished randomised and quasi-randomised trials, including cluster-randomised trials, evaluating any described type of preoperative skin preparation agents, forms, and methods of application for caesarean section were eligible for inclusion. No quasi or cluster-RCTs were identified for inclusion. Cross-over studies were not eligible for inclusion. We included studies presented only as abstracts, if they provided enough information.

\section{Types of participants}

Pregnant women undergoing elective or emergency caesarean section.

\section{Types of interventions}

Comparisons between different antiseptic agents used for caesarean section skin preparation (e.g. alcohol, povidone iodine), different methods of antiseptic application (e.g. scrub, paint, drape), or different forms of antiseptic (e.g. powder, liquid).

We only included studies involving the preparation of the incision area. We excluded studies of preoperative handwashing of the surgical team and preoperative bathing. Other Cochrane Reviews cover other methods for preventing infection at caesarean section (e.g. antimicrobial application, skin shaving).

A related Cochrane Review covers vaginal preparation with antiseptics before caesarean section (Haas 2018).

\section{Types of outcome measures}

\section{Primary outcomes}

1. Surgical site infection (as defined by trialists)

2. Metritis or endometritis, or both

\section{Secondary outcomes}

1. Length of stay

2. Maternal mortality

3. Repeat surgery

4. Re-admission resulting from infection

5. Reduction of skin bacteria colony count ${ }^{\star}$

6. Adverse events (maternal or neonatal)*
*Outcome not prespecified in our published protocol (Hadiati 2008); see Differences between protocol and review.

\section{Search methods for identification of studies}

The following search methods section of this review is based on a standard template used by Cochrane Pregnancy and Childbirth.

\section{Electronic searches}

For this update, we searched Cochrane Pregnancy and Childbirth's Trials Register by contacting their Information Specialist (27 November 2017)

The Register is a database containing over 25,000 reports of controlled trials in the field of pregnancy and childbirth. It represents over 30 years of searching. For full current search methods used to populate Pregnancy and Childbirth's Trials Register including the detailed search strategies for CENTRAL, MEDLINE, Embase and CINAHL; the list of handsearched journals and conference proceedings, and the list of journals reviewed via the current awareness service, please follow this link

Briefly, Cochrane Pregnancy and Childbirth's Trials Register is maintained by their Information Specialist and contains trials identified from:

1. monthly searches of the Cochrane Central Register of Controlled Trials (CENTRAL);

2. weekly searches of MEDLINE (Ovid);

3. weekly searches of Embase (Ovid);

4. monthly searches of CINAHL (EBSCO);

5. handsearches of 30 journals and the proceedings of major conferences;

6. weekly current awareness alerts for a further 44 journals plus monthly BioMed Central email alerts.

Search results are screened by two people and the full text of all relevant trial reports identified through the searching activities described above is reviewed. Based on the intervention described, each trial report is assigned a number that corresponds to a specific Pregnancy and Childbirth review topic (or topics), and is then added to the Register. The Information Specialist searches the Register for each review using this topic number rather than keywords. This results in a more specific search set that has been fully accounted for in the relevant review sections (Included studies; Excluded studies; Ongoing studies).

In addition, we searched ClinicalTrials.gov and the WHO International Clinical Trials Registry Platform (ICTRP) for unpublished, planned, and ongoing trial reports (27 November 2017) using the methods detailed in Appendix 1.

\section{Searching other resources}

We searched the reference lists of all included studies and review articles.

We did not apply any language restrictions.

\section{Data collection and analysis}

For methods used in the previous version, please see Hadiati 2012. 
For this update, we used the following methods, which are based on a standard template used by the Cochrane Pregnancy and Childbirth.

\section{Selection of studies}

Three review authors independently assessed all the potential studies we identified as a result of the search strategy, for inclusion. We resolved any disagreement through discussion, or consulted a fourth person if required.

\section{Data extraction and management}

We designed a form to extract data. We also extracted information on the dates of the study, sources of trial funding, and the trial authors' declarations of interest. For eligible studies, at least two review authors extracted the data, using the agreed form. We resolved discrepancies through discussion, or consulted a third person. if required. We entered data into Review Manager 5 software, and checked for accuracy (RevMan 2014).

\section{Assessment of risk of bias in included studies}

Two review authors independently assessed the risk of bias for each study, using the criteria outlined in the Cochrane Handbook for Systematic Reviews of Interventions (Higgins 2011). We resolved any disagreement by discussion with the third review author.

\section{(1) Random sequence generation (checking for possible selection bias)}

For each included study, we described the method used to generate the allocation sequence in sufficient detail to allow an assessment of whether it should produce comparable groups.

We assessed the method as:

- low risk of bias (any truly random process, e.g. random number table; computer random number generator);

- high risk of bias (any non-random process, e.g. odd or even date of birth; hospital or clinic record number);

- unclear risk of bias.

\section{(2) Allocation concealment (checking for possible selection bias)}

For each included study, we described the method used to conceal the allocation sequence and determine whether intervention allocation could have been foreseen in advance of, or during recruitment, or changed after assignment.

We assessed the methods as:

- low risk of bias (e.g. telephone or central randomisation; consecutively numbered sealed opaque envelopes);

- high risk of bias (open random allocation; unsealed or nonopaque envelopes, alternation; date of birth);

- unclear.

\section{(3.1) Blinding of participants and personnel (checking for} possible performance bias)

For each included study, we described the method used, if any, to blind study participants and personnel from knowledge of which intervention a participant received. We considered that studies were at low risk of bias if they were blinded, or if we judged that the lack of blinding could not have affected the results. We assessed blinding separately for different outcomes or classes of outcomes.

We assessed the methods as:

- low, high, or unclear risk of bias for participants;

- low, high, or unclear risk of bias for personnel.

\section{(3.2) Blinding of outcome assessment (checking for possible detection bias)}

For each included study, we described the method used, if any, to blind outcome assessors from knowledge of which intervention a participant received. We assessed blinding separately for different outcomes or classes of outcomes.

We assessed methods used to blind outcome assessment as:

- low, high, or unclear risk of bias

\section{(4) Incomplete outcome data (checking for possible attrition} bias through withdrawals, dropouts, protocol deviations)

For each included study, and for each outcome or class of outcomes, we described the completeness of data, including attrition and exclusions from the analysis. We stated whether attrition and exclusions were reported, the numbers included in the analysis at each stage (compared with the total randomised participants), reasons for attrition or exclusion where reported, and whether missing data were balanced across groups, or were related to outcomes. Where sufficient information was reported, we re-included missing data in the analyses that we undertook. We assessed methods as:

- low risk of bias (e.g. no missing outcome data; missing outcome data balanced across groups);

- high risk of bias (e.g. numbers or reasons for missing data imbalanced across groups; 'as treated' analysis done with substantial departure of intervention received from that assigned at randomisation);

- unclear risk of bias.

\section{(5) Selective reporting bias}

For each included study, we described how we investigated the possibility of selective outcome reporting bias, and what we found.

We assessed the methods as:

- low risk of bias (where it was clear that all of the study's prespecified outcomes and all expected outcomes of interest to the review were reported);

- high risk of bias (where not all the study's prespecified outcomes were reported; one or more reported primary outcomes were not prespecified; outcomes of interest were reported incompletely and so could not be used; study failed to include results of a key outcome that would have been expected to have been reported);

- unclear risk of bias.

\section{(6) Other sources of bias}

For each included study, we reported any important concerns we had about other possible sources of bias. 
We assessed whether each study was free of other problems that could put it at risk of bias:

- low risk of bias;

- high risk of bias;

- unclear whether there is risk of other bias.

\section{(7) Overall risk of bias}

We made explicit judgements about whether studies were at high risk of bias, according to the criteria given in the Cochrane Handbook for Systematic Reviews of Interventions (Higgins 2011). With reference to (1) to (6) above, we assessed the likely magnitude and direction of the bias, and whether we considered it was likely to impact on the findings. We explored the impact of the level of bias by undertaking sensitivity analyses (see Sensitivity analysis).

\section{Assessment of the quality of the evidence using the GRADE approach}

We used the GRADE approach to evaluate the quality of the evidence, as outlined in the GRADE Handbook (GRADE Handbook; GRADE Working Group 2004). The GRADE approach uses five considerations (study limitations, consistency of effect, imprecision, indirectness, and publication bias) to assess the quality of the body of evidence for specific outcomes. The evidence can be downgraded from 'high quality' by one level for serious (or by two levels for very serious) limitations, depending on assessments for risk of bias, indirectness of evidence, serious inconsistency, imprecision of effect estimates, or potential publication bias (GRADE Working Group 2004; Schünemann 2009). In this review, we used the GRADE approach to assess the following outcomes for all comparisons in the review.

1. Surgical site infection

2. Metritis or endometritis, or both

3. Length of stay*

4. Adverse events (maternal or neonatal)*

*Outcome for GRADE assessment was not prespecified in our previous review (Hadiati 2014); see Differences between protocol and review.

We used GRADEpro GDT to import data from Review Manager 5 to create a 'Summary of findings' table, which presents a summary of the intervention effect and a measure of quality according to the GRADE approach for each of the outcomes listed above (GRADEpro GDT; RevMan 2014).

\section{Measures of treatment effect}

\section{Dichotomous data}

For dichotomous data, we presented results as summary risk ratio with $95 \%$ confidence intervals.

\section{Continuous data}

For continuous outcomes, we used the mean difference with 95\% confidence intervals, as outcomes were measured in the same way between trials. In future updates of this review, if there are trials that measure the same outcome, but use different methods, we will use the standardised mean difference.

\section{Unit of analysis issues}

\section{Cluster-randomised trials}

We did not identify any cluster-randomised trials for inclusion in our review. In future updates, if we identify any cluster-randomised trials, we will include them in the analyses along with individuallyrandomised trials. We will consider it reasonable to combine the results from both if there is little heterogeneity between the study designs and the interaction between the effect of intervention and the choice of randomisation unit is considered to be unlikely. We will adjust their sample sizes using the methods described in the Cochrane Handbook for Systematic Reviews of Interventions, using an estimate of the intracluster correlation co-efficient (ICC) derived from the trial (if possible), from a similar trial, or from a study of a similar population (Higgins 2011). If we use ICCs from other sources, we will report this, and conduct sensitivity analyses to investigate the effect of variation in the ICC.

We will also acknowledge heterogeneity in the randomisation unit, and perform a sensitivity analysis to investigate the effects of the randomisation unit.

\section{Cross-over trials}

Cross-over trials were not eligible for inclusion in this review.

\section{Studies with more than two intervention arms}

If studies included multiple intervention groups, we included only the arms relevant to our research question and each arm was included in the analysis only once (Higgins 2011).

\section{Dealing with missing data}

For included studies, we noted levels of attrition. We explored the impact of including studies with high levels of missing data in the overall assessment of treatment effect with a sensitivity analysis.

For all outcomes, we carried out analyses, as far as possible, on an intention-to-treat basis, i.e. we included all participants randomised to each group in the analyses, and all participants were analysed in the group to which they were allocated, regardless of whether or not they received the allocated intervention. The denominator for each outcome in each trial was the number randomised minus any participants whose outcomes were known to be missing.

\section{Assessment of heterogeneity}

We assessed statistical heterogeneity in each meta-analysis using the $\mathrm{Tau}^{2}, \mathrm{I}^{2}$, and $\mathrm{Chi}^{2}$ statistics. We regarded heterogeneity as substantial if the $\mathrm{I}^{2}$ was greater than $30 \%$, and either the $\mathrm{Tau}^{2}$ was greater than zero, or there was a low $P$ value (less than 0.10 ) in the $\mathrm{Chi}^{2}$ test for heterogeneity.

\section{Assessment of reporting biases}

In future updates, if there are 10 or more studies in the metaanalysis, we will investigate reporting biases (such as publication bias) using funnel plots. We will assess funnel plot asymmetry visually. If asymmetry is suggested by a visual assessment, we will perform exploratory analyses to investigate it (Sterne 2017). 


\section{Data synthesis}

We carried out statistical analysis using Review Manager 5 software (RevMan 2014). We used fixed-effect meta-analysis for combining data where it was reasonable to assume that studies were estimating the same underlying treatment effect: i.e. where trials were examining the same intervention, and the trials' populations and methods were judged to be sufficiently similar. In future updates, if there is sufficient clinical heterogeneity to expect that the underlying treatment effects differ between trials, or if we detect substantial statistical heterogeneity, we will use a random-effects meta-analysis to produce an overall summary, if we consider an average treatment effect across trials is clinically meaningful. We will treat the random-effects summary as the average range of possible treatment effects, and we will discuss the clinical implications of treatment effects differing between trials. If the average treatment effect is not considered to be clinically meaningful, we will not combine trials.

In future updates, if we use random-effects analyses, we will present the results as the average treatment effect with its 95\% confidence interval, and the estimates of $\mathrm{Tau}^{2}$ and $\mathrm{I}^{2}$.

\section{Subgroup analysis and investigation of heterogeneity}

We did not identify substantial heterogeneity. If we do so in future updates of this review, we will investigate it using subgroup analyses and sensitivity analyses. We will consider whether an overall summary is meaningful, and if it is, use random-effects analysis to produce it.

In future updates, we will carry out the following subgroup analyses.
1. Risk of infection (high versus low risk)

2. Duration of skin preparation

3. Dose of preparation

We will restrict subgroup analyses to the primary outcomes.

We will assess differences between subgroups by using interaction tests, as described in the Cochrane Handbook for Systematic Reviews of Interventions (Higgins 2011).

\section{Sensitivity analysis}

We carried out a sensitivity analysis to explore the effects of blinded outcome assessment on the results of the review. Studies in which blinded outcome assessment (for surgical site infection) was inadequate (i.e. high risk of bias) were excluded from the analysis to assess for any substantive difference to the overall result.

In future updates, we will also carry out sensitivity analysis to explore the effect of allocation concealment on the results of the review, and exclude studies with are high risk for this domain. We will also carry out a sensitivity analysis to explore the effects of fixed-effect or random-effects analyses for outcomes with statistical heterogeneity. If, in future updates, we include clusterrandomised trials along with the individually-randomised trials, we will carry out sensitivity analysis to investigate the effect of the randomisation unit.

\section{RESULTS}

\section{Description of studies}

\section{Results of the search}

See: Figure 1. 


\section{Figure 1. Study flow diagram}

Six studies included in the
previous version of the review
(Hadiati 2014).

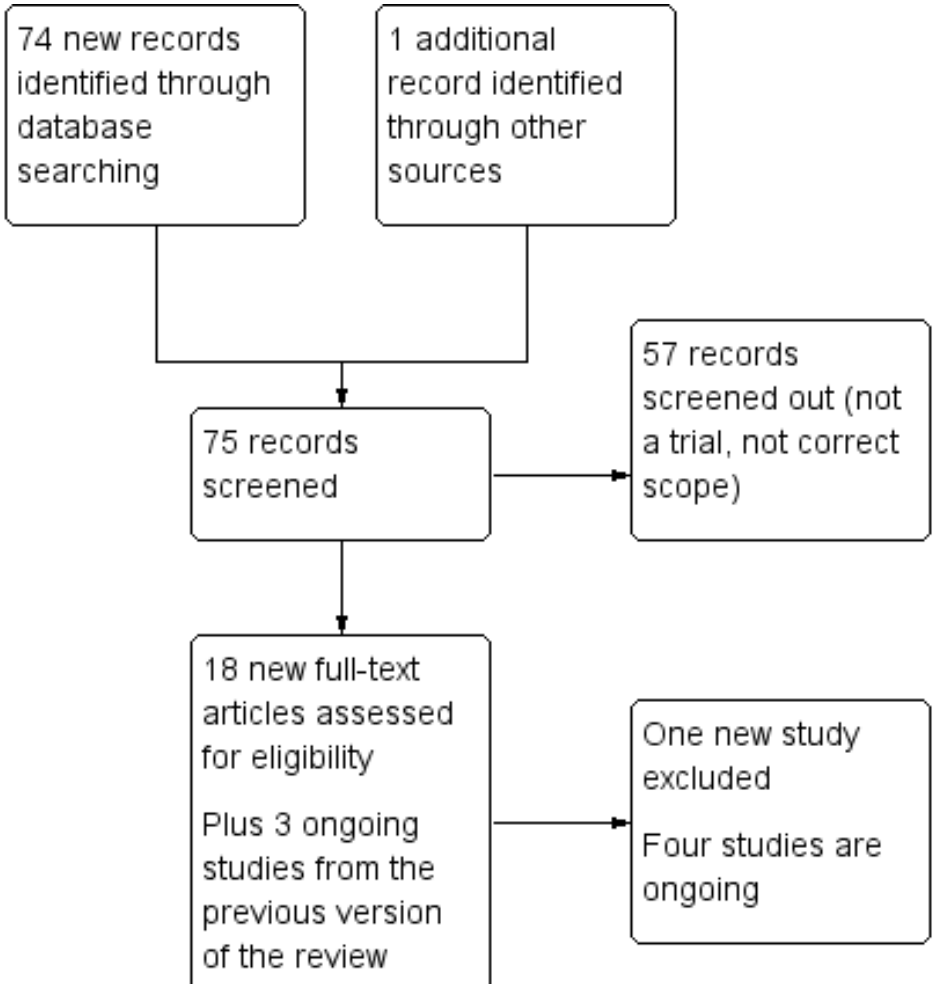

of the review

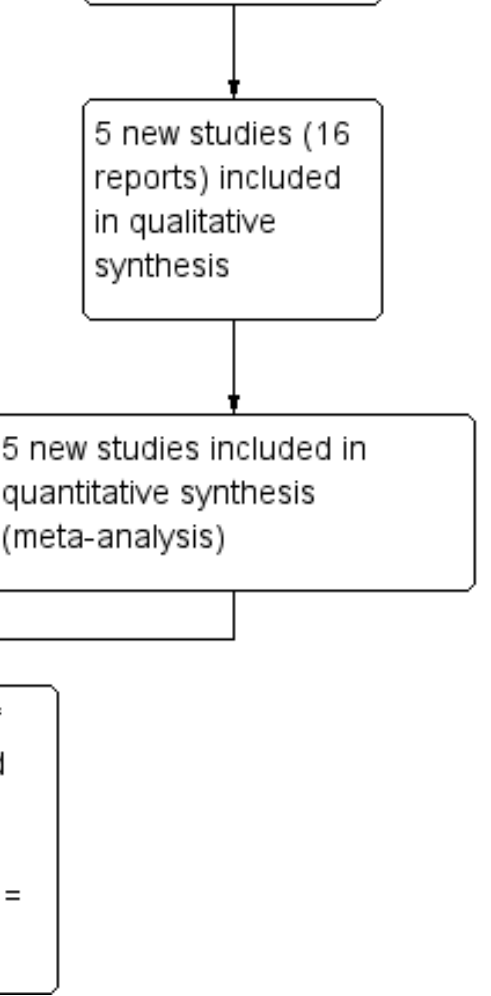

For this update, we assessed 18 new trial reports, and reassessed the three that were ongoing in the previous version of the review (NCT00528008; NCT01472549; NCT01870583). We included five new trials (Aworinde 2016; Fahmi 2017; Ngai 2015; Springel 2017; Tuuli 2016) and excluded one (Nili 2015).
In this review, we included a total of 11 trials comparing different kinds of skin preparation for preventing infection following caesarean section. We obtained full data from nine studies, but only the abstract was available for two studies (Fahmi 2017; Pello 1990). We excluded six trials in total (Brown 1984; Kosus 2010; 
NCT01700803; NCT02027324; Nili 2015; Robins 2005). Four studies are still ongoing (NCT00528008; NCT01870583; NCT02396329; NCT02402907).

\section{Included studies}

We included 11 trials with a total of 6237 women. See Characteristics of included studies.

\section{Method, trial dates, and sample sizes}

All of the included studies were randomised controlled trials (RCTs (Aworinde 2016; Cordtz 1989; Fahmi 2017; Kunkle 2014; Lorenz 1988; Magann 1993; Ngai 2015; Pello 1990; Springel 2017; Tuuli 2016; Ward 2001)). We did not include any quasi- or cluster-RCTs. The trials were conducted between 1983 and 2016. The trial dates were not provided in three studies (Fahmi 2017; Magann 1993; Pello 1990). Sample sizes ranged from 22 women (Pello 1990), to 1404 women (Ngai 2015).

\section{Settings}

Six studies were conducted in the United States (Kunkle 2014; Lorenz 1988; Magann 1993; Ngai 2015; Springel 2017; Tuuli 2016), one study in Denmark (Cordtz 1989), one in France (Pello 1990), one in Nigeria (Aworinde 2016), one in South Africa (Ward 2001), and one study was conducted in Indonesia (Fahmi 2017). Of the included trials, eight were single-centre trials (Aworinde 2016; Kunkle 2014; Lorenz 1988; Magann 1993; Ngai 2015; Springel 2017; Tuuli 2016; Ward 2001), two were conducted in multiple centres (Cordtz 1989; Fahmi 2017), and one trial did not provide any details about the facility (Pello 1990).

\section{Participants}

In Aworinde 2016, women who had elective caesarean section with no overt risk for surgical site infections were included in this trial. Cordtz 1989, Fahmi 2017, Lorenz 1988, Magann 1993, Springel 2017, Tuuli 2016, and Ward 2001 included all women undergoing scheduled caesarean section in their trials. Kunkle 2014 recruited women aged 18 to 45 years undergoing scheduled caesarean delivery at 36 gestational weeks or greater. Participants in Ngai 2015 were all women in their 37th week of gestation, who were undergoing scheduled or non-emergent caesarean delivery. Pello 1990 included women with a male fetus, who were undergoing caesarean section. Most trials stated that they excluded women undergoing emergency caesarean section, with a known sensitivity or allergy to one of the antiseptics used. Three trials gave no or insufficient information about the type of caesarean section (i.e. scheduled or emergency (Cordtz 1989; Pello 1990; Ward 2001)). Tuuli 2016 and Fahmi 2017 included women undergoing both scheduled and emergency caesarean section.

\section{Interventions and comparisons}

\section{Drape versus no drape}

Two trials compared the use of drape versus no drape, and in both studies, the drapes used were not impregnated with an antiseptic agent (Cordtz 1989; Ward 2001). Cordtz 1989 assessed the effect of incisional plastic drapes versus no drape, combined with standard iodine disinfection with $2.5 \%$ iodine in $70 \%$ ethanol for all women. For the purpose of this review, we did not include data from this trial relating to additional arms in which women were re-disinfected, because this secondary disinfection of the skin around the incision took place shortly before skin closure, not before skin incision.
Ward 2001 compared plastic incisional drape with no drape. Before surgery in all women, the abdomen was washed with chlorhexidine soap, and then swabbed with $0.5 \%$ chlorhexidine in $80 \%$ alcohol solution for 30 seconds.

\section{Different antiseptic preparations}

Four different antiseptic preparation comparisons were made in the remaining nine trials. In the Lorenz 1988 trial, the comparison of skin preparation for caesarean section was between a oneminute scrub with $70 \%$ isopropyl alcohol followed by application of iodophor-impregnated adhesive film in the experimental group, versus a five-minute iodophor scrub followed by application of iodophor solution in the control group. The Magann 1993 trial compared a five-minute scrub with parachlorometaxylenol followed by a $10 \%$ povidone-iodine scrub and normal saline irrigation of the pelvis and subcutaneous tissue at uterine closure and fascial closure (special preparation) in the experimental group, versus a $7.5 \%$ povidone-iodine surgical scrub followed by $10 \%$ povidone iodine and normal saline irrigation of the pelvis and subcutaneous tissue at uterine closure and fascial closure (standard preparation) in the control group. The Pello 1990 trial compared two skin preparations using different agents and either drape or no drape (chlorhexidine $0.5 \%$ versus $70 \%$ alcohol plus an IOBAN 2 drape). Six trials compared preoperative application of chlorhexidine gluconate (2\% chlorhexidine gluconate with $70 \%$ isopropyl alcohol) versus povidone iodine $10 \%$, without the use of a drape in either the intervention or control arms (Aworinde 2016; Fahmi 2017; Kunkle 2014; Ngai 2015; Springel 2017; Tuuli 2016).

\section{Outcomes}

\section{Surgical site infection (as defined by trialists)}

Ten studies reported on our primary outcome of surgical site infection (Aworinde 2016; Cordtz 1989; Fahmi 2017; Kunkle 2014; Lorenz 1988; Magann 1993; Ngai 2015; Springel 2017; Tuuli 2016; Ward 2001). Surgical site infection was assessed from delivery to 30 days postoperative in Aworinde 2016, Springel 2017, and Tuuli 2016; at three and seven days postoperative in Fahmi 2017; at three days and two weeks in Kunkle 2014; on two separate measurements at least 24 hours postoperative in Lorenz 1988; on two separate occasions six hours apart after the first 24 hours in Magann 1993; and at two and six weeks postcaesarean in Ngai 2015. Cordtz 1989 did not describe the time of assessment of surgical site infection. Trials used various definitions for surgical site infections. Cordtz 1989 defined a possible wound infection as localised erythema, serous secretion, or both without the presence of pus, and infected as the presence of pus regardless of the results of bacteriological examination. Kunkle 2014 defined surgical site infection as the presence of purulent drainage, cellulitis, or the need for incision and drainage, or treatment with antibiotics for a clinical diagnosis of infection. In Lorenz 1988, surgical site infection was defined as infectious morbidity with (1) erythema and tenderness of the wound or separation of skin edges, and (2) no uterine tenderness or malodorous, discoloured lochia. Magann 1993 defined this outcome as hyperemic skin incision and a fluctuant mass, which when opened, contained purulent material. In Ward 2001, surgical site infection was diagnosed if two of three features were present: (1) erythematous cellulitis, (2) seropurulent discharge from the wound, and (3) positive swab culture (organisms and leucocytes). Fahmi 2017, Ngai 2015, Springel 2017, and Tuuli 2016 based the diagnosis of surgical site infection on Centers for Disease Control 
and Prevention (CDC) criteria. One trial did not define surgical site infection in the report (Aworinde 2016).

\section{Metritis or endometritis, or both}

Four trials reported on endometritis (Lorenz 1988; Magann 1993; Springel 2017; Tuuli 2016). In Lorenz 1988, endomyometritis was defined as infectious morbidity with either (1) uterine tenderness on bimanual examination, or (2) no other site of infection identified on physical examination, urinalysis, or urine culture, and if indicated, a chest roentgenogram. In Magann 1993, endometritis was identified through physical examination, urine, and blood cultures. Springel 2017 followed the definition of endometritis according to the CDC, and Tuuli 2016 did not provide any definition for this outcome.

\section{Length of stay}

Tuuli 2016 and Ward 2001 reported our secondary outcome, length of stay. However, Tuuli 2016 reported only median length of hospital stay, so we only described data narratively.

\section{Re-admission resulting from infection}

Two trials reported on re-admission resulting from infection (Springel 2017; Tuuli 2016).

\section{Reduction of skin bacteria colony count}

Lorenz 1988 reported on reduction of skin bacteria colony counts, and Kunkle 2014 reported on bacterial growth at 18 hours.

\section{Adverse events (maternal or neonatal)}

Two trials reported on maternal adverse events involving skin reactions, with both reporting on erythema and skin irritation (Aworinde 2016; Tuuli 2016). Only one trial reported on neonatal adverse events, which was the concentration of iodine in the cord blood (Pello 1990). No other maternal or neonatal adverse events were reported.

The other outcomes investigated by this review, maternity mortality and repeated surgery, were not been reported in any of the included trials.

\section{Sources of trial funding}

Seven trials did not mention source of funding (Cordtz 1989; Fahmi 2017; Lorenz 1988; Magann 1993; Ngai 2015; Pello 1990; Ward 2001).
The Obafemi Awowolowo University Teaching Hospital Complex, Nigeria supported Aworinde 2016. The University of Southern California supported Kunkle 2014 , and Edward Henry Springel, MD supported Springel 2017. Tuuli 2016 received funding from the Women's Reproductive Health Research Career Development grant from the Eunice Kennedy Shriver National Institute of Child Health and Human Development of the National Institutes of Health, and the Department of Obstetrics and Gynecology, Washington University School of Medicine in St. Louis.

\section{Trialists' declarations of interest}

Eight studies did not report declarations of interest (Aworinde 2016; Cordtz 1989; Fahmi 2017; Lorenz 1988; Magann 1993; Ngai 2015; Pello 1990; Ward 2001). Two studies stated no conflict of interest (Kunkle 2014; Springel 2017). In Tuuli 2016, the first author reported having received a grant from the National Institutes of Health during the conduct of the study, but all other authors declared no conflict of interest.

\section{Excluded studies}

We excluded six trials (Brown 1984; Kosus 2010; NCT01700803; NCT02027324; Nili 2015; Robins 2005). The Brown 1984 study was excluded as the trial did not present the results for caesarean section cases separately from other surgical cases. The Kosus 2010 trial was excluded as they used an antibiotic compared with or without Rifamycin SV $(250 \mathrm{mg}$ ) before closure of subcutaneous tissue, in addition to povidone iodine $10 \%$ for preoperative antisepsis and after closure of the skin. Two trials (NCT01700803; NCT02027324) were excluded as they focused on preoperative handwashing of the surgical team. We excluded one study because it was a cohort study and not a randomised controlled trial (Nili 2015). Robins 2005 compared the effectiveness of chlorhexidine spray and single use sachets for skin preparation before regional nerve blockade, not for the preparation of the incision site before caesarean section.

For further details of the excluded studies, see Characteristics of excluded studies.

\section{Risk of bias in included studies}

See 'Risk of bias' tables and figures for the 11 included studies in Characteristics of included studies, Figure 2, and Figure 3. 
Figure 2. 'Risk of bias' graph: review authors' judgements about each risk of bias item presented as percentages across all included studies

Random sequence generation (selection bias)

Allocation concealment (selection bias)

Blinding of participants and personnel (performance bias)

Blinding of outcome assessment (detection bias)

Incomplete outcome data (attrition bias)

Selective reporting (reporting bias)

Other bias
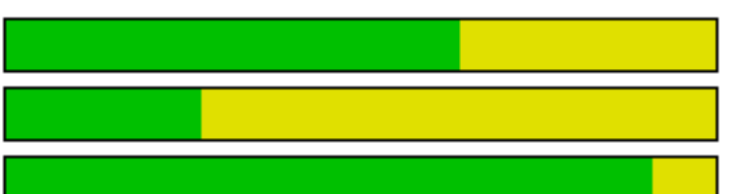

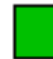

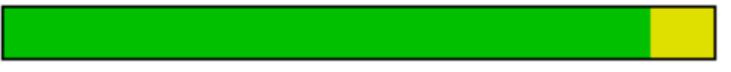

L

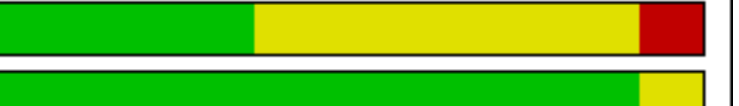

\begin{tabular}{lllll}
\hline $0 \%$ & $25 \%$ & $50 \%$ & $75 \%$ & $100 \%$
\end{tabular}


Figure 3. 'Risk of bias' graph: review authors' judgements about each risk of bias item for each included study

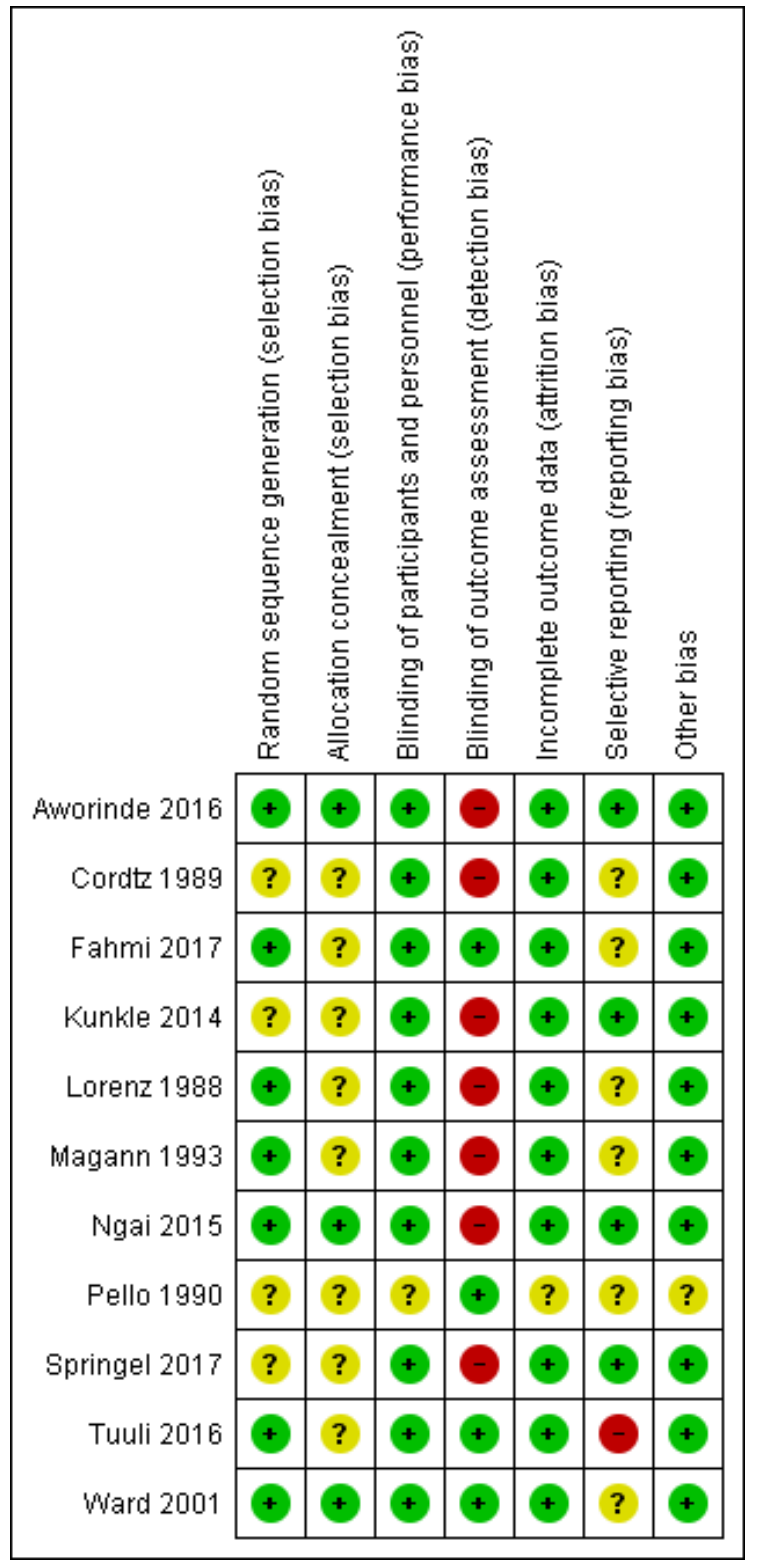

\section{Allocation}

\section{Sequence generation}

Sequence generation (computer-generated sequence) was adequate in seven trials (Aworinde 2016; Fahmi 2017; Lorenz 1988; Magann 1993; Ngai 2015; Tuuli 2016; Ward 2001). The remaining four trials provided insufficient or no details about sequence generation, and therefore, we judged them to be of unclear risk of bias (Cordtz 1989; Kunkle 2014; Pello 1990; Springel 2017).

\section{Allocation concealment}

The majority of included trials provided insufficient or no details regarding the measures taken to ensure that the treatment allocation could not be foreseen, and so we assessed them as unclear risk of bias for this item (Cordtz 1989; Fahmi 2017; Kunkle 2014; Lorenz 1988; Magann 1993; Pello 1990; Springel 2017; Tuuli 2016). In three trials, allocation concealment was performed using sequentially numbered sealed envelopes, so we assessed the trials at low risk of bias (Aworinde 2016; Ngai 2015; Ward 2001).

\section{Blinding}

\section{Blinding of participants and personnel (performance bias)}

Although blinding was not reported in most of the trials, it was unlikely that this lack of blinding could have caused different treatments or behaviour between groups, such that outcomes would be affected, and therefore, we judged performance bias to be low in 10 trials (Aworinde 2016; Cordtz 1989; Fahmi 2017; Kunkle 2014; Lorenz 1988; Magann 1993; Ngai 2015; Springel 2017; Tuuli 2016; Ward 2001). In Pello 1990, the information provided was too limited to exclude any performance bias. 


\section{Blinding of outcome assessment (detection bias)}

Seven trials were at high risk of detection bias (Aworinde 2016; Cordtz 1989; Kunkle 2014; Lorenz 1988; Magann 1993; Ngai 2015; Springel 2017). In these trials, outcome assessors were not blinded, and some outcomes involved an important element of subjective assessment. It was possible that lack of blinding could have caused differences in the reported outcomes, especially with respect to our primary outcome of surgical site infection, and therefore, this brings into question the certainty of the estimated treatment effect. Outcome assessment was blinded in three trials, so we judged them at low risk of bias (Fahmi 2017; Tuuli 2016; Ward 2001). In Pello 1990, blinding of outcome assessment was not described, but lack of blinding was unlikely to affect the outcome because it was objectively measured, and therefore was at low risk of bias.

\section{Incomplete outcome data}

In 10 trials, we judged attrition bias to be low, as all women were followed up until the end of the study, or the number of missing participants was balanced between intervention groups, and it was unlikely that the missing data substantially influenced the outcomes (Aworinde 2016; Cordtz 1989; Fahmi 2017; Kunkle 2014; Lorenz 1988; Magann 1993; Ngai 2015; Springel 2017; Tuuli 2016; Ward 2001). Only one study out of the 11 included studies was judged as unclear risk of bias, because the number of women in each group was not reported (Pello 1990).

\section{Selective reporting}

We found no evidence of selective reporting in four trials, and assessed them at low risk of bias (Aworinde 2016; Kunkle 2014; Ngai 2015; Springel 2017). Protocols were not available for us to assess originally planned outcomes in six trials, and so these we assessed as unclear risk of reporting bias (Cordtz 1989; Fahmi 2017; Lorenz 1988; Magann 1993; Pello 1990; Ward 2001). We judged the Tuuli 2016 study as being at a high risk of reporting bias, because some prespecified outcomes were not reported in the trial report.

\section{Other potential sources of bias}

Overall, we judged all the included trials to be at low risk of bias for other potential sources of bias. In the Cordtz 1989 trial, antibiotics for prophylaxis therapy were given to about $10 \%$ of the women in the study. Even though more women in the drape group (10.7\%) received antibiotics than in the group without drapes (8.2\%), infections were more common in the drape group. Therefore, the 'real' effect of skin preparation may have been different, but this was likely to be small, because of the overall small difference between groups. In the Lorenz 1988, Magann 1993, and Kunkle 2014 trials, the use of prophylaxis antibiotics was not specified in the study report. Pello 1990 did not provide enough information to exclude other bias.

\section{Effects of interventions}

See: Summary of findings for the main comparison Drape compared to no drape before caesarean section for preventing infection; Summary of findings 2 One-minute alcohol scrub with iodophor drape compared to five-minute iodophor scrub without drape for preventing infection following caesarean section; Summary of findings 3 Parachlorometaxylenol with iodine versus iodine alone for preventing infection following caesarean section; Summary of findings 4 Chlorhexidine gluconate compared to povidone iodine for preventing infection following caesarean section

We included 11 trials, involving 6237 women, in this review. One small study, involving 22 women, only reported neonatal outcomes, and did not contribute any data towards any of the prespecified outcomes of this review (Pello 1990). We were only able to conduct meta-analyses for comparisons one (two trials) and four (six trials).

\section{Comparison 1: Drape versus no drape}

Two trials, involving 1945 women, contributed data to this comparison (Cordtz 1989; Ward 2001). See Summary of findings for the main comparison

\section{Primary outcomes}

\section{Surgical site infection}

For women undergoing caesarean section, low-quality evidence suggested that using a drape before surgery compared with no drape may make little or no difference to surgical site infection (risk ratio (RR) $1.29,95 \% \mathrm{Cl} 0.97$ to $1.71 ; 2$ trials, 1294 women; low-quality evidence; Analysis 1.1).

\section{Metritis or endometritis, or both}

No data were reported for metritis, endometritis, or both, in either of the included studies for this comparison.

\section{Secondary outcomes}

\section{Length of stay}

The length of stay was measured in one trial involving 603 women, which compared the use of a drape with no drape (Ward 2001). Moderate-quality evidence suggested that the use of a drape probably makes little or no difference to the length of time spent in hospital (mean difference (MD) 0.10 day, $95 \% \mathrm{Cl}-0.27$ to 0.46 ; Analysis 1.2).

\section{Maternal mortality}

No data were reported for maternal mortality in either of the included studies.

\section{Repeat surgery}

No data were reported for repeated surgery in either of the included studies.

\section{Re-admission resulting from infection}

No data were reported for re-admission resulting from infection in either of the included studies.

\section{Reduction of skin bacteria colony count}

No data were reported for skin bacteria colony count in either of the included studies.

\section{Adverse events (maternal or neonatal)}

No data were reported for adverse events for mother or baby in either of the included studies. 
Comparison 2: One-minute alcohol scrub with iodophor drape versus five-minute iodophor scrub without drape

One trial, involving 79 women, assessed the effects of a one-minute alcohol scrub with an iodophor drape compared with a five-minute iodophor scrub without a drape before caesarean section (Lorenz 1988). See Summary of findings 2

\section{Primary outcomes}

\section{Surgical site infection}

There were no surgical site infections in either the group that received an alcohol scrub and iodophor drape or those who received an iodophor scrub only ( 1 trial, 79 women; very low-quality evidence; Analysis 2.1).

\section{Metritis or endometritis, or both}

We were uncertain whether the combination of a one-minute alcohol scrub with an iodophor drape clearly reduced the occurrence of endomyometritis when compared with a five-minute iodophor scrub, because the quality of the evidence was very low (RR $1.62,95 \% \mathrm{Cl} 0.29$ to 9.16; 1 trial, 79 women; very low-quality evidence; Analysis 2.2).

\section{Secondary outcomes}

Length of stay

No data were reported for length of stay.

\section{Maternal mortality}

No data were reported for maternal mortality.

\section{Repeat surgery}

No data were reported for repeated surgery.

\section{Re-admission resulting from infection}

No data were reported for re-admission resulting from infection.

\section{Reduction of skin bacteria colony count}

The single trial providing data on this comparison suggested that there may be little or no difference between groups for reduced skin bacteria colony counts (MD 0.07 colony forming unit per plate, $95 \%$ $\mathrm{Cl}-0.34$ to 0.48 ; 1 trial, 79 women; Analysis 2.3 ).

\section{Adverse events (maternal or neonatal)}

No adverse events were reported for mother or baby in the included study.

\section{Comparison 3: Parachlorometaxylenol with iodine versus iodine alone}

One trial, involving 50 women, contributed data to this comparison (Magann 1993). See Summary of findings 3

\section{Primary outcomes}

\section{Surgical site infection}

We were uncertain if parachlorometaxylenol with iodine made any clear difference to the reduction of surgical site infection when compared with iodine alone, because the quality of the evidence was very low (RR $0.33,95 \% \mathrm{Cl} 0.04$ to $2.99 ; 1$ trial, 50 women; very low-quality evidence; Analysis 3.1).

\section{Metritis or endometritis, or both}

We were uncertain if parachlorometaxylenol with iodine made any difference to the reduction of metritis, endometritis, or both, when compared with iodine alone, because the quality of the evidence was very low (RR $0.88,95 \% \mathrm{Cl} 0.56$ to $1.38 ; 1$ trial, 50 women; very low-quality evidence; Analysis 3.2).

\section{Secondary outcomes}

\section{Length of stay}

No data were reported for length of stay.

Maternal mortality

No data were reported for maternal mortality.

\section{Repeat surgery}

No data were reported for repeated surgery.

Re-admission resulting from infection

No data were reported for re-admission resulting from infection.

Reduction of skin bacteria colony count

No data were reported for reduction of skin bacteria colony count.

\section{Adverse events (maternal or neonatal)}

No adverse events were reported for mother or baby in the included study.

\section{Comparison 4: Chlorhexidine gluconate verus povidone iodine}

Six trials, involving 4091 women, contributed data to this comparison (Aworinde 2016; Fahmi 2017; Kunkle 2014; Ngai 2015; Springel 2017; Tuuli 2016). See Summary of findings 4

\section{Primary outcomes}

\section{Surgical site infection}

Low-quality evidence suggested that there may be little or no difference between chlorhexidine gluconate and povidone iodine applied before caesarean section in reducing surgical site infection (RR $0.80,95 \% \mathrm{Cl} 0.62$ to 1.02 ; 6 trials, 3607 women; low-quality evidence; Analysis 4.1). However, surgical site infection appeared to be slightly reduced for women who were prepared with chlorhexidine gluconate compared with povidone iodine (RR 0.59, $95 \% \mathrm{Cl} 0.37$ to $0.95 ; \mathrm{P}=0.03 ; 2$ trials, 1321 women) after removing four trials at high risk of bias for outcome assessment in a sensitivity analyses (Aworinde 2016; Kunkle 2014; Ngai 2015; Springel 2017).

\section{Metritis or endometritis, or both}

Low-quality evidence indicated that using chlorhexidine gluconate before caesarean section, when compared with povidone iodine, may make little or no difference to the reduction of endometritis (RR $1.01,95 \% \mathrm{Cl} 0.51$ to 2.01 ; 2 trials, 2079 women; low-quality evidence; Analysis 4.2).

\section{Secondary outcomes}

\section{Length of stay}

In Tuuli 2016, a median length of hospital stay of four days (interquartile range three to four days) was reported for both the chlorhexidine gluconate group and the povidone-iodine group; there was no difference in these reported data between groups. 


\section{Maternal mortality}

No data were reported for maternal mortality in any of the included studies.

\section{Repeat surgery}

No data were reported for repeated surgery in any of the included studies.

\section{Re-admission resulting from infection}

The results from two trials reporting on this ocutome suggested that there may be little or no difference in re-admissions due to infection between the chlorhexidine gluconate and the povidoneiodine groups (RR $0.71,95 \% \mathrm{Cl} 0.43$ to $1.19 ; 2$ trials, 2079 women; Analysis 4.3).

\section{Reduction of skin bacteria colony count}

Results from one small trial suggested that women who received chlorhexidine gluconate skin preparation may have slightly reduced bacterial growth at 18 hours after caesarean section compared with women who received skin preparation with povidone iodine ( $\mathrm{RR} 0.23,95 \% \mathrm{Cl} 0.07$ to $0.70 ; 1$ trial, 60 women; Analysis 4.4).

\section{Adverse events (maternal or neonatal)}

Low-quality evidence suggested that there may be little or no difference in skin reactions between those who had chlorhexidine gluconate skin preparation before caesarean section compared with those who had povidone skin preparation (RR $0.79,95 \% \mathrm{Cl}$ 0.32 to $1.96 ; 1$ trial, 374 women), in erythema (RR 1.13, $95 \% \mathrm{Cl}$ 0.57 to 2.26 ; 2 trials, 1521 women), or in skin irritation or allergic skin reaction ( $\mathrm{RR} 0.60,95 \% \mathrm{Cl} 0.22$ to $1.63 ; 2$ trials, 1521 women; low-quality evidence; Analysis 4.5). No neonatal adverse events were reported in the included studies.

\section{Comparison 5: Chlorhexidine $\mathbf{0 . 5} \%$ versus $70 \%$ alcohol plus drape}

One trial involving 22 women assessed this comparison (Pello 1990).

\section{Primary outcomes}

\section{Surgical site infection}

No data were reported for surgical site infection.

\section{Metritis or endometritis, or both}

No data were reported for metritis or endometritis, or both.

\section{Secondary outcomes}

Length of stay

No data were reported for length of stay.

\section{Maternal mortality}

No data were reported for maternal mortality.

\section{Repeat surgery}

No data were reported for repeated surgery.

\section{Re-admission resulting from infection}

No data were reported for re-admission resulting from infection.

\section{Reduction of skin bacteria colony count}

No data were reported for reduction of skin bacteria colony count.

\section{Adverse events (maternal or neonatal)}

Pello 1990 compared skin preparation with chlorhexidine $0.5 \%$ and $70 \%$ alcohol with a drape (IOBAN 2), and reported the newborn's exposure to iodine. Cord blood iodine concentration (CBI) was higher in the IOBAN 2 drape group $(18.38 \pm 20.34$ versus $6.44 \pm 0.66$ $\mu \mathrm{g} / 100 \mathrm{~mL} ; \mathrm{P}<0.05)$. There was no clear difference between the two groups in 48-hour urine iodine excretion or thyroid-stimulating hormone (TSH) blood concentration on the fifth day. No maternal adverse events were reported in the included study.

\section{DISCUSSION}

\section{Summary of main results}

This updated review included 11 trials and 6237 women, 10 trials and 6215 women of which contributed data to the meta-analyses. In relation to the primary outcomes of surgical site infection, and metritis or endometritis, our analyses suggested that there may be little or no difference between different skin preparations for caesarean section. One comparison, where we found that there was probably little or no difference between chlorhexidine gluconate and povidone iodine in preventing surgical site infection, was based on six trials including 3607 women. We assessed the evidence for this result to be of low quality due to a wide confidence interval, indicating that the true effect might in fact be substantially different. However, surgical site infection appeared to be slightly reduced for patients receiving chlorhexidine gluconate skin preparation rather than povidone iodine, after our sensitivity analysis removed four trials at high risk of bias for outcome assessment (Aworinde 2016; Kunkle 2014; Ngai 2015; Springel 2017). The evidence for the other comparisons between skin preparations in this review all came from only one or two trials, involved small numbers of women, and also yielded effect estimates with wide confidence intervals in most cases. There were also wide-ranging methodological concerns regarding study design. In some studies, it was not possible to know whether randomisation processes were adequate, and we were particularly concerned about the high number of studies where there was no blinding of subjective assessments relating to infection. Moreover, in assessing surgical site infection, pooled results may have also been only indirectly comparable, due to variability between the included studies in the criteria used to assess surgical site infection.

Regarding the secondary outcomes, we found that there may be little or no difference between chlorhexidine gluconate and povidone iodine for maternal skin irritation or allergic skin reaction. However, the included trials provided either very little or no data for almost all of our specified secondary outcomes, most notably, adverse neonatal effects, maternal mortality, or repeat surgery. Therefore, this review was limited in its power to detect meaningful differences between antiseptic agents and methods of skin preparation, with respect to most of the outcomes under consideration.

\section{Overall completeness and applicability of evidence}

Of the 11 included trials, five were reasonably large, while the other six trials each recruited only small numbers of women. Ten trials contributed to the evaluation of four main comparisons, limiting the ability to pool results (we were only able to carry out 
meta-analysis for two comparisons). Ten trials reported on surgical site infection, while four trials reported on endometritis; only one to two trials reported on the remaining outcomes, or not at all. Therefore, it was not possible to fully address the objectives of this review.

\section{Quality of the evidence}

We are unable to draw robust conclusions regarding the different agents and methods of skin preparation for preventing infection following caesarean section. The body of evidence was too small; although we included 11 studies involving 6237 women, the evidence available for each comparison and outcome under investigation reported on too few women and was too limited in scope.

The included studies were subject to some important methodological limitations. Regarding the primary outcome of surgical site infection, most of the studies did not blind outcome assessors, and we could not always be confident in the adequacy of randomisation processes. When we assessed the quality of the evidence using GRADE criteria, we found it ranged from very low to moderate. For surgical site infection, we found low qualityevidence when comparing chlorhexidine gluconate with povidone iodine, due to a wide $95 \%$ confidence interval and lack of blinding for outcome assessment (Summary of findings 4). We found low-quality and moderate-quality evidence when comparing the use of a drape versus no drape, and very-low quality evidence when comparing parachlorometaxylenol with iodine versus iodine alone, due to wide confidence intervals crossing the line of no effect and small sample sizes, and lack of blinding of outcome assessment (Summary of findings for the main comparison; Summary of findings 3). We found very low-quality evidence for a one-minute alcohol scrub plus an iodophor drape versus a fiveminute iodophor scrub without a drape, due to unclear risk of bias for allocation concealment and blinding of outcome assessment, and small sample size with no events (Summary of findings 2).

\section{Potential biases in the review process}

We believe it is unlikely that we missed any eligible published studies, because of the comprehensive search strategy employed by Cochrane Pregnancy and Childbirth. However, there may be relevant unpublished trials that we were unable to locate. Screening of the studies and data extraction were carried out independently by at least two review authors, therefore ensuring reliable data were available for the review. Hadiati is a named author on Fahmi 2017, but was not involved in the screening process and risk of bias assessment.

\section{Agreements and disagreements with other studies or reviews}

The Cochrane Review of skin preparation for clean surgery found preoperative skin preparation with $0.5 \%$ chlorhexidine in methylated spirits was associated with lower rates of surgical site infections following clean surgery than alcohol-based povidone iodine, which is consistent with our findings (Dumville 2015). Rather than iodine alone, alternate chlorhexidine might be effective, although the evidence for both comparisons was low quality. We need to interpret the results with caution. However, caesarean section is regarded as 'clean-contaminated' surgery, and so the effect of antiseptic skin preparation may be more evident for this type of surgery because of exposure to both internal and external sources of infection during birth. Because of the limited quality of the evidence presently available, we were unable to explore this hypothesis further in this review.

\section{AUTHORS' CONCLUSIONS}

\section{Implications for practice}

From the included studies, we found insufficient evidence to determine what types of skin preparations may be most effective for preventing postcaesarean wound and surgical site infections.

Most of the evidence in this review was deemed to be very low or low quality. This means that for most findings, our confidence in any evidence of an intervention effect is limited, and indicates the need for more high-quality research.

We found four studies that were ongoing; we will incorporate the results of these studies in future updates of this review.

\section{Implications for research}

There is a need for high-quality, well-designed, randomised controlled trials in this field, with larger sample sizes. Proper randomisation, adequate allocation concealment, blinding of participants, clinicians, outcome assessors (especially where outcomes involve subjective assessment) and data analysts, plus clear attrition policies are essential to ensure appropriate comparisons between groups. The priority comparisons in superiority or non-inferiority trials could include type of antiseptic (especially iodine versus chlorhexidine), the timing and duration of applying the antiseptic (especially previous night versus day of surgery), and application methods (scrubbing, swabbing, and draping). Various maternal and neonatal outcome measurements could be considered, i.e. length of stay, maternal mortality, repeat surgery, and re-admission resulting from infection, including surgical site infection, and any adverse events. Furthermore, there is a need for consistency of definitions in future trials for outcomes, such as surgical site infection.

\section{ACKNOWLEDGEMENTS}

For the first version of this review, the review authors would like to thank staff from the Australasian Cochrane Centre for technical support during the preparation of the review, and sincerely acknowledge Philippa Middleton and Miranda Cumpston for their supportive advice and comments to improve the review. The Faculty of Medicine, Gadjah Mada University, Yogyakarta, Indonesia provided support for Diah Hadiati and Detty Nurdiati to travel to Australia to finish the first version of this review.

Diah Hadiati wrote the protocol as a part of a SEA-ORCHID Project Fellowship at the Australasian Cochrane Centre, and wishes to acknowledge the support provided by Steve McDonald and Tari Turner.

As part of the pre-publication editorial process, this review was commented on by three peers (an editor and two referees who were external to the editorial team), a member of Cochrane Pregnancy and Childbirth's international panel of consumers, and the Group's Statistical Adviser.

This project was supported by the National Institute for Health Research, via Cochrane Infrastructure funding to Cochrane 
Pregnancy and Childbirth. The views and opinions expressed therein are those of the authors and do not necessarily reflect those of the Systematic Reviews Programme, NIHR, NHS, or the Department of Health.
For the 2014 update, Erika Ota's work was financially supported by the UNDP/UNFPA/UNICEF/WHO/World Bank Special Programme of Research, Development, and Research Training in Human Reproduction (HRP), Department of Reproductive Health and Research (RHR), World Health Organization. The named authors alone are responsible for the views expressed in this publication. 


\section{RE F E R E N C E S}

\section{References to studies included in this review}

Aworinde 2016 \{published data only\}

* Aworinde O, Olufemi-Aworinde K, Fehintola A, Adeyemi B, Owonikoko M, Adeyemi AS. Antiseptic skin preparation for preventing surgical site infection at caesarean section. Open Journal of Obstetrics and Gynecology 2016;6:246-51.

PACTR201401000697382. Comparative study of antiseptic skin preparation for preventing surgical site infection at caesarean section: a randomised control trial. pactr.org/ATMWeb/appmanager/atm/atmregistry? dar=true\&tNo=PACTR201401000697382 (first received 5 November 2013).

\section{Cordtz 1989 \{published data only\}}

Cordtz T, Schouenborg L, Laursen K, Daugaard HO, Buur K, Munk Christensen B, et al. The effect of incisional plastic drapes and redisinfection of operation site on wound infection following caesarean section. Journal of Hospital Infection 1989;13(3):267-72. [PUBMED: 2567756]

\section{Fahmi 2017 \{published data only\}}

Fahmi MN, Hadiati DR, Widad S. Comparison of skin preparation with alcohol-chlorhexidine versus alcohol-povidone iodine on surgical site infection following caesarean section. Journal of Obstetrics and Gynaecology Research 2017;43:38.

Kunkle 2014 \{published data only\}

* Kunkle CM, Marchan J, Safadi S, Whitman S, Chmait RH. Chlorhexidine gluconate versus povidone iodine at cesarean delivery: a randomized controlled trial. Journal of MaternalFetal \& Neonatal Medicine 2015; Vol. 28, issue 5:573-7. [DOI: $10.3109 / 14767058.2014 .926884]$

Murray C, Marchan J, Safadi S, Opper N, Yedigarova L, Chmait R. Efficacy of chlorhexidine gluconate versus povidone iodine for skin disinfection at cesarean section: a randomized controlled trial. American Journal of Obstetrics and Gynecology 2012;206(Suppl 1):S152-3.

NCT01975805. Chlorhexidine gluconate versus povidone iodine at cesarean delivery: a randomized controlled trial. clinicaltrials.gov/ct2/show/NCT01975805. (first received 5 November 2013).

\section{Lorenz 1988 \{published data only\}}

Lorenz RP, Botti JJ, Appelbaum PC, Bennett N. Skin preparation methods before cesarean section. Journal of Reproductive Medicine 1988;33(2):202-4.

\section{Magann 1993 \{published data only\}}

Magann EF, Dodson MK, Ray MA, Harris RL, Martin JN, Morrison JC. Preoperative skin preparation and intraoperative pelvic irrigation: impact on endometritis following Cesarean delivery. 41st Annual Clinical Meeting of the American College of Obstetricians and Gynecologists; 1993 May 3-6; Washington DC, USA. 1993:11.
* Magann EF, Dodson MK, Ray MA, Harris RL, Martin JN, Morrison JC. Preoperative skin preparation and intraoperative pelvic irrigation: impact on post-cesarean endometritis and wound infection. Obstetrics and Gynecology 1993;81(6):922-5. [PUBMED: 8497357]

\section{Ngai 2015 \{published data only\}}

Maiwald M. Skin preparation for prevention of surgical site infection after cesarean delivery: a randomized controlled trial. Obstetrics and Gynecology 2017;129(4):750-1.

Ngai I, Govindappagari S, Van Arsdale A, Judge NE, Neto N, Bernstein J, et al. Skin preparation in cesarean birth for prevention of surgical site infection (SSI): a prospective randomized clinical trial. American Journal of Obstetrics and Gynecology 2015;212(1 Suppl 1):S424.

* Ngai IM, Van Arsdale A, Govindappagari S, Judge NE, Neto NK, Bernstein J, et al. Skin preparation for prevention of surgical site infection after cesarean delivery: a randomized controlled trial. Obstetrics and Gynecology 2015;126(6):1251-7.

Pello 1990 \{published data only\}

* Pello JY, Pons G, Leger FA, Moisson-Tardieu MT, DailheDupont D, Francoual C, et al. Ioban 2 for cesarean section operative field: study of innocuity for the newborn. Therapie 1990;45:85.

\section{Springel 2017 \{published data only\}}

NCT02202577. Chlorhexidine-alcohol versus povidoneiodine for surgical site antisepsis prior to cesarean delivery. clinicaltrials.gov/ct2/show/NCT02202577 (first received 29 July 2014).

Springel EH, Sarfoh V, Stetzer B, Weight S, Mercer B, Wang XY. $A$ randomized controlled trial of chlorhexidine-alcohol versus povidone-iodine for cesarean antisepsis. American Journal of Obstetrics and Gynecology 2017;216(1 Suppl):S30, Abstract no: 42. [NCT02202577]

* Springel EH, Wang XY, Sarfoh VM, Stetzer BP, Weight SA, Mercer BM. A randomized open-label controlled trial of chlorhexidine-alcohol versus povidone-iodine for cesarean antisepsis: the CAPICA trial. American Journal of Obstetrics and Gynecology 2017;217:463.e1-8.

Tuuli 2016 \{published data only\}

NCT01472549. Antiseptic skin preparation for preventing surgical site infection at cesarean delivery: a randomized comparative effectiveness trial. clinicaltrials.gov/show/ NCT01472549 (first received November 2011).

Stout MJ, Martin S, Cahill AG, Macones GA, Tuuli MG. Impact of chlorhexidine-alcohol versus iodine-alcohol skin antisepsis on methicillin-resistant staphylococcus aureus infection after cesarean. American Journal of Obstetrics and Gynecology 2016;214(1 Suppl):S119, Abstract no: 194. [NCT01472549]

Temming LA, Raghuraman N, Carter EB, Stout MJ, Rampersad RM, Macones GA, et al. Impact of evidence-based interventions on wound complications after cesarean delivery. 
American Journal of Obstetrics \& Gynecology 2017; Vol. 217, issue 4:449.e1-9.

Temming LA, Raghuraman N, Stout MJ, Cahill AG, Macones GA, Tuuli MG. Impact of evidence based interventions on wound complications after cesarean. American Journal of Obstetrics and Gynecology 2017;216(1):S106, Abstract no: 158.

Tuuli MG, Liu J, Stout MJ, Martin S, Cahill AG, Colditz G, et al. Chlorhexidine-alcohol compared with iodine-alcohol for preventing surgical-site infection at cesarean: a randomized controlled trial. American Journal of Obstetrics and Gynecology 2016;214(1 Suppl):S3, Abstract no: 4.

* Tuuli MG, Liu J, Stout MJ, Martin S, Cahill AG, Odibo AO, et al. A randomized trial comparing skin antiseptic agents at cesarean delivery. New England Journal of Medicine 2016;374(7):647-55.

Tuuli MG, Woolfolk C, Stout MJ, Temming L, Cahill AG, Macones GA. Does the relative efficacy of chlorhexidine-alcohol versus iodine-alcohol antisepsis differ between unscheduled and scheduled cesareans?. American Journal of Obstetrics and Gynecology 2016;214(1 Suppl):S120, Abstract no: 196. [NCT01472549]

\section{Ward 2001 \{published data only\}}

Ward HRG, Jennings OGN, Potgieter P, Lombard CJ. Do adhesive plastic drapes prevent post caesarean wound infection?. Journal of Hospital Infection 2001;47:230-4.

\section{References to studies excluded from this review}

Brown 1984 \{published data only\}

Brown TR, Ehrlich CE, Stehman FB, Golichowski AM, Madura JA, Eitzen $\mathrm{HE}$. A clinical evaluation of chlorhexidine gluconate spray as compared with iodophor scrub for preoperative skin preparation. Surgery, Gynecology and Obstetrics 1984;158(4):363-6.

\section{Kosus 2010 \{published data only\}}

Kosus A, Kosus N, Guler A, Capar M. Rifamycin SV application to subcutaneous tissue for prevention of post-cesarean surgical site infection [Sezaryen sonrasi kesi yeri enfeksiyonunu onlemek icin ciltalti rifamisin SV uygulanmasi]. European Journal of General Medicine 2010;7(3):269-76.

NCT01700803 \{published data only\}

NCT01700803. Povidone iodine and cesarean section wound infections. clinicaltrials.gov/ct2/show/NCT01700803 (first received 4 October 2012)

\section{NCT02027324 \{published data only\}}

NCT02027324. Prevention of surgical site infection after cesarean delivery (CAPISSI). clinicaltrials.gov/ct2/show/ NCT02027324 (first received 6 Janury 2014).

\section{Nili 2015 \{published data only\}}

IRCT201204289568N1. Studying the relationship between neonatal hypothyroidism and using iodine and non iodine containing disinfectants before caesarian section in icteric neonates that refer to clinic of neonates in Valiasr hospital. en.irct.ir/trial/10126 (first registered 07 July 2012).
Nili F, Hantoushzadeh S, Alimohamadi A, Shariat M, Rezaeizadeh $\mathrm{G}$. lodine-containing disinfectants in preparation for caesarean section: impact on thyroid profile in cord blood. Postgraduate Medical Journal 2015;91:681-84.

Robins 2005 \{published data only\}

Robins K, Wilson R, Watkins EJ, Columb MO, Lyons G. Chlorhexidine spray versus single use sachets for skin preparation before regional nerve blockade for elective caesarean section: an effectiveness, time and cost study. International Journal of Obstetric Anesthesia 2005;14(3):189-92.

\section{References to ongoing studies \\ NCT00528008 \{published data only\}}

NCT00528008. A comparison of surgical preparations and wound infection rates for elective cesarean sections. clinicaltrials.gov/ct2/show/NCT00528008 (first received 11 September 2007).

\section{NCT01870583 \{published data only\}}

NCT01870583. Comparison of surgical skin preps during cesarean deliveries. clinicaltrials.gov/ct2/show/record/ NCT01870583 (first received 6 June 2013).

\section{NCT02396329 \{published data only\}}

NCT02396329. Chlorhexidine versus povidone-iodine antisepsis for reduction of post cesarean section surgical site infection rate:a randomized controlled trial. clinicaltrials.gov/ct2/show/ NCT02396329 (first received 1 March 2015).

\section{NCT02402907 \{published data only\}}

NCT02402907. A randomized trial to determine if a preoperative wash with a chlorhexidine cloth reduces infectious morbidity in patients undergoing cesarean section. clinicaltrials.gov/ct2/show/NCT02402907 (first received 30 March 2015).

\section{Additional references}

\section{AORN 2002}

Association of Operating Room Nurses. Recommended practices for skin preparation of patients. AORN Journal 2002;75:184-7.

\section{CDC 2005}

Centers for Disease Control and Prevention. Data and statistics for surgical site infections. www.cdc.gov/ncidod/dhqp/ dpac_ssi_data.html (accessed: 5 August 2008).

\section{Cunningham 2018}

Cunningham FG, Leveno KJ, Bloom SL, Spong CY, Dashe JS, Hoffman BL, et al. Puerperal complications. In: Hoffman BL editor(s). Williams Obstetrics. 25th Edition. McGraw-Hill Education, 2018.

\section{Dumville 2015}

Dumville JC, McFarlane E, Edwards P, Lipp A, Holmes A, Liu Z. Preoperative skin antiseptics for preventing surgical wound 
infections after clean surgery. Cochrane Database of Systematic Reviews 2015, Issue 4. [DOI: 10.1002/14651858.CD003949.pub4]

\section{GRADE Handbook}

Schünemann H, Brożek J, Guyatt G, Oxman A, editor(s). Handbook for grading the quality of evidence and the strength of recommendations using the GRADE approach (updated October 2013). GRADE Working Group, 2013. Handbook for grading the quality of evidence and the strength of recommendations using the GRADE approach (updated October 2013). GRADE Working Group, 2013.

\section{GRADE Working Group 2004}

GRADE Working Group. Grading quality of evidence and strength of recommendations. BMJ 2004;328:1490-4.

\section{GRADEpro GDT [Computer program]}

McMaster University (developed by Evidence Prime). GRADEpro GDT. Version accessed prior to 26 September 2018. Hamilton (ON): McMaster University (developed by Evidence Prime), 2015.

\section{Haas 2018}

Haas DM, Morgan S, Contreras K, Enders S. Vaginal preparation with antiseptic solution before cesarean section for preventing postoperative infections. Cochrane Database of Systematic Reviews 2018, Issue 7. [DOI: 10.1002/14651858.CD007892.pub6]

\section{Hardin 1997}

Hardin W, Nichols R. Handwashing and patient skin preparation. In: Malangoni MA editor(s). Critical Issues in Operating Room Management. Philadelphia: Lippincott-Raven, 1997:133-44.

\section{Henderson 1995}

Henderson E, Love EJ. Incidence of hospital-acquired infections associated with caesarean section. Journal of Hospital Infection 1995;29:245-55.

\section{Higgins 2011}

Higgins JPT, Green S, editor(s). Cochrane Handbook for Systematic Reviews of Interventions Version 5.1.0 (updated March 2011). The Cochrane Collaboration, 2011. Available from handbook.cochrane.org.

\section{Larson 1988}

Larson E. Guideline for use of topical antimicrobial agents. American Journal of Infection Control 1988;16:253-66.

\section{Leaper 2001}

Leaper DJ, Orr C, Maung Z, White A. Inflammation and Infection: STEP 2000 Module II.. Royal College of Surgeons of England: Blackwell Science, 2001.

\section{Leclair 1990}

Leclair J. A review of antiseptics. Cleansing agents. Todays $O R$ Nurse 1990;12(10):25-8.

\section{Lewis 2013}

Lewis SS, Moehring RW, Chen LF, Sexton DJ, Anderson DJ. Assessing the relative burden of hospital-acquired infections in a network of community hospitals. Infection Control and
Hospital Epidemiology 2013;34(11):1229-30. [PUBMED: 24113613]

\section{Loudon 2002}

Loudon I. Ignaz Phillip Semmelweis' studies of death in childbirth. www.jameslindlibrary.org (accessed: 5 August 2008).

\section{Mangram 1999}

Mangram JA, Horan TC, Pearson ML, Silver LC, Jarvis WR. Guideline for prevention of surgical site infection. Infection Control and Hospital Epidemiology 1999;20:247-78.

\section{Martin 2015}

Martin JA, Hamilton BE, Osterman MJK, Driscoll AK, Mathews TJ. Births: Final Data for 2015. National Vital Statistics Report 2017;66(1):1. [PUBMED: 28135188]

\section{Mathai 2013}

Mathai M, Hofmeyr GJ, Mathai NE. Abdominal surgical incisions for caesarean section. Cochrane Database of Systematic Reviews 2013, Issue 5. [DOI: 10.1002/14651858.CD004453.pub3]

\section{NCT01472549}

NCT01472549. Antiseptic skin preparation for preventing surgical site infection at cesarean delivery: a randomized comparative effectiveness trial. clinicaltrials.gov/show/ NCT01472549 (first received November 2011).

\section{Normand 2001}

Normand MC, Damato EG. Postcesarean infection. JOGNN - Journal of Obstetric, Gynecologic, \& Neonatal Nursing 2001;30(6):642-8.

\section{RevMan 2014 [Computer program]}

Nordic Cochrane Centre, The Cochrane Collaboration. Review Manager 5 (RevMan 5). Version 5.3. Copenhagen: Nordic Cochrane Centre, The Cochrane Collaboration, 2014.

\section{Schünemann 2009}

Schünemann HJ. GRADE: from grading the evidence to developing recommendations. A description of the system and a proposal regarding the transferability of the results of clinical research to clinical practice [GRADE: Von der Evidenz zur Empfehlung. Beschreibung des Systems und Losungsbeitrag zur Ubertragbarkeit von Studienergebnissen]. Zeitschrift fur Evidenz, Fortbildung und Qualitat im Gesundheitswesen 2009;103(6):391-400. [PUBMED: 19839216]

\section{Sterne 2017}

Sterne JAC, Egger M, Moher D, Boutron I, editor(s). Chapter 10: Addressing reporting biases. In: Higgins JPT, Churchill R, Chandler J, Cumpston MS, editor(s), Cochrane Handbook for Systematic Reviews of Interventions version 5.2.0 (updated June 2017), Cochrane, 2017. Available from www.training.cochrane.org/handbook.

\section{Thomas 2001}

Thomas J, Paranjothy S, Royal College of Obstetricians and Gynaecologists Clinical Effectiveness Support Unit. National Sentinel Caesarean Section Audit Report. London: RCOG Press, 2001. 


\section{Vogel 2015}

Vogel JP, Betran AP, Vindevoghel N, Souza JP, Torloni MR, Zhang J, et al. Use of the Robson classification to assess caesarean section trends in 21 countries: a secondary analysis of two WHO multicountry surveys. Lancet Global health 2015;3(5):e260-70. [DOI: 10.1016/S2214-109X(15)70094-X; PUBMED: 25866355]

\section{WHO 2015}

World Health Organization. WHO Statement on Caesarean Section Rates. www.who.int/reproductivehealth/publications/ maternal_perinatal_health/cs-statement/en/ 2015.

\section{References to other published versions of this review \\ Hadiati 2008}

Hadiati DR, Hakimi M, Nurdiati DS. Skin preparation for preventing infection following caesarean section. Cochrane

\section{CHARACTERISTICS OF STUDIES}

Characteristics of included studies [ordered by study ID]
Database of Systematic Reviews 2008, Issue 4. [DOI: 10.1002/14651858.CD007462]

\section{Hadiati 2012}

Hadiati DR, Hakimi M, Nurdiati DS. Skin preparation for preventing infection following caesarean section. Cochrane Database of Systematic Reviews 2012, Issue 9. [DOI: 10.1002/14651858.CD007462.pub2]

\section{Hadiati 2014}

Hadiati DR, Hakimi M, Nurdiati DS, Ota E. Skin preparation for preventing infection following caesarean section. Cochrane Database of Systematic Reviews 2014, Issue 9. [DOI: 10.1002/14651858.CD007462.pub3]

* Indicates the major publication for the study

Aworinde 2016

Methods Computer-generated randomised control trial

Participants

All women $(\mathrm{N}=374)$ who had elective caesarean section with no overt risk for surgical site infection were randomised into 2 groups.

The trial was carried out in the Department of Obstetrics and Gynaecology of the Obafemi Awolowo University Teaching Hospitals Complex (OAUTHC), Ile-Ife, Osun State, Nigeria.

Interventions All women had a bath with non-antiseptic soap before surgery. Shaving of the lower abdomen was done on the surgical table, just before commencing antiseptic skin preparation.

For women who fell into the chlorhexidine-alcohol group $(\mathrm{N}=188)$, skin preparation was done with gauze soaked in Valon (containing Chlorhexidine gluconate $0.3 \%$ weight/volume $(\mathrm{w} / \mathrm{v})$ and Cetrimide $3.0 \% \mathrm{w} / \mathrm{v}$ manufactured by Royal priesthood laboratory ltd), which was diluted with distilled water in a 1:1 ratio. A centrifugal scrubbing motion was used, starting from the area of the intended incision and covered the abdomen from the subcostal margin to the midaxillary line down to the middle of the thigh. This was repeated twice. The area was then dried with a piece of dry gauze in the same centrifugal manner. Moko ${ }^{\circledR}$ (containing Isopropyl alcohol 95\% v/v manufactured by New-Health way Co. Limited) was then applied on the area in the same centrifugal manner and allowed to dry before draping of the area.

For women in the povidone-iodine group ( $N=186)$, Wosan ${ }^{\circledast}$ (containing $10 \%$ povidone iodine manufactured by Jawa international limited) was used. The povidone iodine was painted on the aforementioned area and then left to dry completely before draping the area and commencing the surgery.

Outcomes Surgical site infections in 30 days after delivery. Bacterial culture for wounds assessed as infected. Development of skin reaction.

Definition of surgical site infection: not provided.

Notes All women were given prophylactic antibiotic (intravenous cefuroxime 750 mg immediately (stat)), ad-
ministered after clamping of the cord.

The surgery was done under spinal anaesthesia.

Pan African Clinical Trials Registry No. PACTR201401000697382 
Trial dates: August 2012 to July 2013

Sources of trial funding: Obafemi Awowolowo University Teaching Hospital Complex, Nigeria

Trialist declarations of interest: not reported

\section{Risk of bias}

\begin{tabular}{lll}
\hline Bias & Authors' judgement & Support for judgement \\
\hline $\begin{array}{l}\text { Random sequence genera- } \\
\text { tion (selection bias) }\end{array}$ & Low risk & Quote: "...computer generated random sequence". \\
\hline $\begin{array}{l}\text { Allocation concealment } \\
\text { (selection bias) }\end{array}$ & Low risk & $\begin{array}{l}\text { Quote: "...sequentially numbered sealed packets..." and "The sealed en- } \\
\text { velopes were placed in the labour ward theatre and were drawn from serially } \\
\text { by the surgeons just before the procedure". }\end{array}$
\end{tabular}

Blinding of participants Low risk
and personnel (perforQuote: "Blinding both patients and physicians to the antiseptic used for skin mance bias) preparation (double-blinding) would have been ideal, however, it was not fea-

All outcomes sible in this trial".

Comment: unlikely that this lack of blinding of participants and personnel could have caused different treatments between groups.

\begin{tabular}{|c|c|c|}
\hline $\begin{array}{l}\text { Blinding of outcome as- } \\
\text { sessment (detection bias) } \\
\text { All outcomes }\end{array}$ & High risk & $\begin{array}{l}\text { Quote: "Blinding both patients and physicians to the antiseptic used for skin } \\
\text { preparation (double-blinding) would have been ideal, however, it was not fea- } \\
\text { sible in this trial". }\end{array}$ \\
\hline & & $\begin{array}{l}\text { Comment: it is possible that this lack of blinding of outcome assessors could } \\
\text { account for the different treatment effects between groups, because surgical } \\
\text { site infection involves subjective assessment. }\end{array}$ \\
\hline
\end{tabular}

Incomplete outcome data Low risk Quote: "Ten were excluded from the analysis due to the fact that they were lost
(attrition bias) to follow-up or ended up having a midline scar".

Comment: the number of excluded women was similar between intervention groups: chlorhexidine-alcohol group 4/192 (2.1\%) and povidone-iodine group $6 / 192(3.1 \%)$.

Selective reporting (re- Low risk The same outcomes reported in the trial registry
porting bias)

\begin{tabular}{ll}
\hline Other bias $\quad$ Low risk & Other bias was not noticed during review \\
\hline
\end{tabular}

\section{Cordtz 1989}

\begin{tabular}{ll}
\hline Methods & Randomised multicentre 4-group trial \\
\hline Participants & All women undergoing caesarean section $(\mathrm{N}=1340)$ \\
& The trial was a Danish multicentre trial where 8 Danish hospitals participated under supervision of the \\
& National Center for Hospital Hygiene, Statens Seruminstitut. \\
\hline
\end{tabular}

Interventions

The study had 4 experimental groups: with or without drape and with or without re-disinfection. For the purpose of this review we only included a comparison of drapes versus no drapes, with standard disinfection, not re-disinfection. 
Experimental group $(\mathrm{N}=337)$ incisional plastic drape was applied to the skin after preoperative skin disinfection.

Control group ( $\mathrm{N}=354)$ no drape was used. All women received preoperative skin disinfection of $2.5 \%$ iodine in $70 \%$ ethanol.

Surgical site infection in 14 days after delivery
Definition of surgical site infection: (1) Possible wound infection: localized erythema, serous secretion,
or both, without presence of pus; (2) Infected: presence of pus, regardless of the results of bacteriolog-
ical examination. Pus could be classified as superficially or subfascially located. Incision for drainage
was also reported.

Notes

We did not include the re-disinfection group, as it was defined as disinfection of the skin around the incision shortly before skin closure.

Antibiotics for prophylaxis therapy were used in 36 of 337 women (10.7\%) in the drape group and 29 of 354 women $(8.2 \%)$ in the no drape group.

Trial dates: September 1985 to May 1986

Type of anaesthesia not described

Sources of trial funding: not reported

Trialist declarations of interest: not reported

\section{Risk of bias}

Bias Authors' judgement Support for judgement

Random sequence genera- Unclear risk tion (selection bias)
Quote: "blocks of eight consecutive patient numbers were labelled... in random order".

Comment: although the method of determining random order was not specified, given the numbers in the trial, it is probable that this was generated by computer or random tables.

\begin{tabular}{lll}
\hline $\begin{array}{l}\text { Allocation concealment } \\
\text { (selection bias) }\end{array}$ & Unclear risk & Not stated \\
\hline $\begin{array}{l}\text { Blinding of participants } \\
\begin{array}{l}\text { and personnel (perfor- } \\
\text { mance bias) }\end{array}\end{array}$ & Low risk & $\begin{array}{l}\text { Blinding was not described, but is likely that participant and personnel could } \\
\text { identify different interventions. Unlikely that this lack of blinding could have } \\
\text { All outcomes }\end{array}$ \\
\hline
\end{tabular}

$\begin{array}{lll}\text { Blinding of outcome as- } & \text { High risk } \quad \text { No blinding stated, and some outcome measurements were subjective. }\end{array}$
sessment (detection bias)

All outcomes 
Fahmi 2017

\begin{tabular}{ll}
\hline Methods & Multicenter, randomised clinical trial \\
\hline Participants & All women undergoing scheduled or emergency caesarean section \\
& $\begin{array}{l}\text { The study was conducted in Dr Sardjito hospital and } 2 \text { affiliated hospital (Saras Husada Hospital and } \\
\text { Panembahan Senopati Hospital), Indonesia. }\end{array}$ \\
\hline Interventions & Alcohol-chlorhexidine group $(\mathrm{N}=87)$ and alcohol-povidone-iodine group $(\mathrm{N}=87)$ \\
\hline Outcomes & Surgical site infections on day 3 and day 7 after caesarean section \\
& $\begin{array}{l}\text { Definition of surgical site infection: diagnosed based on Centers for Disease Control and Prevention } \\
\text { (CDC) criteria }\end{array}$ \\
\hline
\end{tabular}

Notes We have the full thesis from the author in Indonesian

All women received preoperative prophylactic antibiotic cefotaxim 1 hour before skin incision.

Type of anaesthesia not described

Trial dates: June 2013 to May 2014

Sources of trial funding: not reported

Trialist declarations of interest: not reported

\section{Risk of bias}

\begin{tabular}{|c|c|c|}
\hline Bias & Authors' judgement & Support for judgement \\
\hline \multirow{2}{*}{$\begin{array}{l}\text { Random sequence genera- } \\
\text { tion (selection bias) }\end{array}$} & Low risk & Quote: "...subjects were randomly divided into two groups...". \\
\hline & & $\begin{array}{l}\text { Comment: computer-generated random sequence (information provided by } \\
\text { trial author) }\end{array}$ \\
\hline $\begin{array}{l}\text { Allocation concealment } \\
\text { (selection bias) }\end{array}$ & Unclear risk & Allocation concealment was not described. \\
\hline $\begin{array}{l}\text { Blinding of participants } \\
\text { and personnel (perfor- } \\
\text { mance bias) } \\
\text { All outcomes }\end{array}$ & Low risk & $\begin{array}{l}\text { Blinding was not described, but is likely that participants and personnel could } \\
\text { identify different interventions. Unlikely that this lack of blinding could have } \\
\text { caused different treatments between groups. }\end{array}$ \\
\hline $\begin{array}{l}\text { Blinding of outcome as- } \\
\text { sessment (detection bias) } \\
\text { All outcomes }\end{array}$ & Low risk & $\begin{array}{l}\text { Researchers and outcome assessors did not know the type of intervention (in- } \\
\text { formation provided by trial author). }\end{array}$ \\
\hline $\begin{array}{l}\text { Incomplete outcome data } \\
\text { (attrition bias) }\end{array}$ & Low risk & All women were followed until the 7 th day after caesarean section. \\
\hline $\begin{array}{l}\text { Selective reporting (re- } \\
\text { porting bias) }\end{array}$ & Unclear risk & $\begin{array}{l}\text { There was no protocol to access, so we did not know the originally planned } \\
\text { outcomes. }\end{array}$ \\
\hline
\end{tabular}


Fahmi 2017 (Continued)

Other bias Low risk Other bias was not noticed during review.

Kunkle 2014

\begin{tabular}{ll}
\hline Methods & A single-centre, randomised controlled trial \\
\hline Participants & $\begin{array}{l}\text { Women aged } 18 \text { to } 45 \text { years, undergoing scheduled caesarean delivery at } 36 \text { gestational weeks or later. } \\
\text { The trial was conducted at the University of Southern California Los Angeles County Medical Center, } \\
\text { United States. }\end{array}$ \\
\hline $\begin{array}{l}60 \text { participants were included: chlorhexidine gluconate group (N=27) versus povidone-iodine group (P } \\
\text { Interventions }\end{array}$ & $\begin{array}{l}\text { Surgical site infection at } 3 \text { days and } 2 \text { weeks. Positive bacterial culture rates at } 3 \text { minutes and } 18 \text { hours } \\
\text { Outcomes } \\
\text { and drainage, or treatment with antibiotics for a clinical diagnosis of infection }\end{array}$ \\
\hline Type of anaesthesia not described. \\
Clinical Trials.gov. identifier: NCT01975805 need for incision \\
Trial dates: January 2010 to March 2012 \\
Sources of trial funding: University of Southern California \\
Trialist declarations of interest: reported, no conflict of interest
\end{tabular}

\section{Risk of bias}

Bias Authors' judgement Support for judgement

Random sequence genera- Unclear risk tion (selection bias)

Quote: "The choice of disinfectant was determined by simple randomization where each participant was independently assigned to either PI or CG without any regard for previous patient assignments".

Comment: no specific randomisation methods stated

\begin{tabular}{|c|c|c|}
\hline $\begin{array}{l}\text { Allocation concealment } \\
\text { (selection bias) }\end{array}$ & Unclear risk & Comment: no information provided \\
\hline $\begin{array}{l}\text { Blinding of participants } \\
\text { and personnel (perfor- } \\
\text { mance bias) }\end{array}$ & Low risk & $\begin{array}{l}\text { Quote: "The operating surgeons could not be blinded because both agents } \\
\text { possess distinctly different coloring when applied to the skin". }\end{array}$ \\
\hline All outcomes & & $\begin{array}{l}\text { Comment: unlikely that this lack of blinding could have caused different treat- } \\
\text { ments between groups }\end{array}$ \\
\hline
\end{tabular}

Blinding of outcome as- High risk sessment (detection bias)

All outcomes
No blinding stated, but outcome assessment of surgical site infection was subjective, while bacterial culture rates were objective measurements.

\begin{tabular}{lll}
\hline $\begin{array}{l}\text { Incomplete outcome data } \\
\text { (attrition bias) }\end{array}$ & Low risk & Outcome data were reported for all women. \\
\hline $\begin{array}{l}\text { Selective reporting (re- } \\
\text { porting bias) }\end{array}$ & Low risk & The same outcomes reported in the trial registry \\
\hline
\end{tabular}


Kunkle 2014 (Continued)

Other bias Low risk Other bias was not noticed during review.

Lorenz 1988

\begin{tabular}{|c|c|}
\hline Methods & Randomised clinical trial using a table of random numbers \\
\hline \multirow[t]{2}{*}{ Participants } & $\begin{array}{l}\text { All women undergoing caesarean section. The women were excluded if they were allergic to iodine, } \\
\text { younger than } 18 \text { years of age, had chorioamnionitis, refused to participate, emergency clinical circum- } \\
\text { stances prevented adequate informed consent, or no culture plate available. }\end{array}$ \\
\hline & The trial was conducted at Pennsylvania State University, Hersey, USA \\
\hline \multirow[t]{3}{*}{ Interventions } & A total of 79 women were included. \\
\hline & $\begin{array}{l}\text { Experimental group }(\mathrm{N}=38) \text { received a 1-minute scrub with } 70 \% \text { isopropyl alcohol followed by applica- } \\
\text { tion of iodophor-impregnated adhesive film. }\end{array}$ \\
\hline & $\begin{array}{l}\text { Control group }(\mathrm{N}=41) \text { received a } 5 \text {-minute iodophor scrub followed by application of iodophor solu- } \\
\text { tion. }\end{array}$ \\
\hline \multirow[t]{2}{*}{ Outcomes } & $\begin{array}{l}\text { Endomyometritis, surgical site infection (assessed on } 2 \text { separate measurements at least } 24 \mathrm{~h} \text { postoper- } \\
\text { atively), and reduction of skin bacteria colony counts. All participants had skin bacterial counts before } \\
\text { skin preparation and immediately postoperatively. }\end{array}$ \\
\hline & $\begin{array}{l}\text { Definition of surgical site infection: infectious morbidity (body temperature }>38^{\circ} \mathrm{C} \text { on } 2 \text { separate mea- } \\
\text { surements at least } 24 \mathrm{~h} \text { postoperatively) with (1) erythema and tenderness of the wound or separation } \\
\text { of skin edges, and (2) uterine tenderness or malodorous, discoloured lochia }\end{array}$ \\
\hline \multirow[t]{4}{*}{ Notes } & Type of anaesthesia not described \\
\hline & Trial dates: June 1983 to April 1984 \\
\hline & Sources of trial funding: not reported \\
\hline & Trialist declarations of interest: not reported \\
\hline
\end{tabular}

\section{Risk of bias}

\begin{tabular}{|c|c|c|}
\hline Bias & Authors' judgement & Support for judgement \\
\hline $\begin{array}{l}\text { Random sequence genera- } \\
\text { tion (selection bias) }\end{array}$ & Low risk & $\begin{array}{l}\text { Quote: "Each patient was randomly assigned, using a table of random num- } \\
\text { ber...". }\end{array}$ \\
\hline $\begin{array}{l}\text { Allocation concealment } \\
\text { (selection bias) }\end{array}$ & Unclear risk & The allocation was not described \\
\hline $\begin{array}{l}\text { Blinding of participants } \\
\text { and personnel (perfor- } \\
\text { mance bias) } \\
\text { All outcomes }\end{array}$ & Low risk & $\begin{array}{l}\text { Blinding was not described, but is likely that participants and personnel could } \\
\text { have identified the different interventions. It is unlikely that lack of blinding } \\
\text { could have caused different caesarean treatment relevant to the outcomes. }\end{array}$ \\
\hline $\begin{array}{l}\text { Blinding of outcome as- } \\
\text { sessment (detection bias) } \\
\text { All outcomes }\end{array}$ & High risk & No blinding stated and some outcome measurements were subjective. \\
\hline $\begin{array}{l}\text { Incomplete outcome data } \\
\text { (attrition bias) }\end{array}$ & Low risk & All women were followed up to the end of the study. \\
\hline
\end{tabular}


Lorenz 1988 (Continued)

$\begin{array}{ll}\begin{array}{l}\text { Selective reporting (re- } \\ \text { porting bias) }\end{array} & \text { Unclear risk } \\ \end{array}$

Other bias Low risk Other bias was not noticed during review.

\section{Magann 1993}

Methods Randomised trial using a table of random numbers

Participants All women undergoing caesarean section.

The exclusion criteria were chorioamnionitis, emergency for caesarean section for fetal distress with inadequate time for skin preparation, and refusal to participate.

The trial was conducted at the University of Mississippi Medical Center, USA.

Interventions A total of 100 women were included and divided into 4 subgroups of 25 women. For the purpose of this
review the following 2 groups were included.

Experimental group $(\mathrm{N}=25)$ received a 5 -minute scrub with parachlorometaxylenol followed by povidone-iodine solution and normal saline irrigation of the pelvis and subcutaneous tissue at uterine closure and fascial closure.

Control group ( $\mathrm{N}=25)$ received a povidone-iodine surgical scrub $(7.5 \%)$ followed by povidone iodine $(10 \%)$ and normal saline irrigation of the pelvis and subcutaneous tissue at uterine closure and fascial closure.

\begin{tabular}{ll}
\hline Outcomes & $\begin{array}{l}\text { Endometritis and surgical site infection } \\
\text { Definition of surgical site infection: hyperemic skin incision and a fluctuant mass, that when opened, } \\
\text { contained purulent material }\end{array}$ \\
\hline Notes & Type of anaesthesia: general, spinal or epidural \\
& Trial dates: not reported \\
Sources of trial funding: not reported \\
Trialist declarations of interest: not reported
\end{tabular}

\section{Risk of bias}

Bias Authors' judgement Support for judgement

\begin{tabular}{|c|c|c|}
\hline $\begin{array}{l}\text { Random sequence genera- } \\
\text { tion (selection bias) }\end{array}$ & Low risk & $\begin{array}{l}\text { Quote: "This randomised study ... with group appointment derived from a ran- } \\
\text { dom number table". }\end{array}$ \\
\hline & & $\begin{array}{l}\text { Comment: it was unclear what 'card selection' involved, and therefore, } \\
\text { whether investigators could have foreseen assignment. }\end{array}$ \\
\hline
\end{tabular}

\begin{tabular}{|c|c|c|}
\hline $\begin{array}{l}\text { Blinding of participants } \\
\text { and personnel (perfor- } \\
\text { mance bias) }\end{array}$ & Low risk & $\begin{array}{l}\text { Blinding was not described, but it is likely that participants and personnel } \\
\text { could identify different interventions. It is unlikely that this lack of blinding } \\
\text { could have caused different caesarean treatment relevant to the outcomes. }\end{array}$ \\
\hline All outcomes & & \\
\hline
\end{tabular}


Magann 1993 (Continued)

Blinding of outcome as- High risk No blinding stated and some outcome measurements were subjective. sessment (detection bias)

All outcomes

$\begin{aligned} & \text { Incomplete outcome data } \\ & \text { (attrition bias) }\end{aligned} \quad$ Low risk women were followed up to the end of the study.

\begin{tabular}{|c|c|c|}
\hline $\begin{array}{l}\text { Selective reporting (re- } \\
\text { porting bias) }\end{array}$ & Unclear risk & $\begin{array}{l}\text { There was no protocol to access, so we did not know the originally planned } \\
\text { outcomes. }\end{array}$ \\
\hline
\end{tabular}

Other bias Low risk Other bias was not noticed during review.

\section{Ngai 2015}

$\begin{array}{ll}\text { Methods } & \text { Computer-generated randomisation through www.radomisation.com with alternating block sizes of } 6 \\ \text { and } 12\end{array}$

Participants All women at 37 weeks of gestation, based on best obstetric estimate, who were undergoing scheduled or non-emergent caesarean delivery.

Women were excluded if they had a urogenital tract infection within 2 weeks of delivery and if they were younger than 18 years old.

The trial was conducted at 2 Montefiore Medical Center, Einstein Medical College, NY, United States.

The 1404 participants were enrolled in a 1:1:1 fashion to 1 of 3 groups: povidone iodine with alcohol
group (PA group: $N=462$ ), chlorhexidine with alcohol group (CA group: $N=467)$, and combination of
povidone iodine with alcohol, and chlorhexidine with alcohol used together (BOTH group: $N=465)$.

For the purpose of this review, we compared the PA group and CA group.

Surgical site infections on 2 and 6 weeks postcaesarean
Definition of surgical site infection: according to Horan and colleagues. and the Centers for Disease
Control and Prevention. A surgical site infection outcome was defined as the patient reporting the
requirement of antibiotic use for a wound infection, or documented wound infection in the medical
record at the outpatient visit within 30 days of discharge.

Notes All women received preoperative prophylactic antibiotics within 1 hour of skin incision. Surgical drapes
were placed after a minimum of 4 minutes drying time.

All women had regional anaesthesia, a spinal, epidural, or combined spinal and epidural.

ClinicalTrials.gov Identifier: NCT01870583

Trial dates: January 2013 to July 2014

Sources of trial funding: the study provided no support for a particular method of skin preparation

Trialist declarations of interest: not reported

\section{Risk of bias}

\begin{tabular}{lll}
\hline Bias & Authors' judgement & Support for judgement \\
\hline $\begin{array}{l}\text { Random sequence genera- } \\
\text { tion (selection bias) }\end{array}$ & Low risk & $\begin{array}{l}\text { Quote: "Randomization was computer-generated through www.randomiza- } \\
\text { tion.com with alternating block sizes of six and 12". }\end{array}$ \\
\hline
\end{tabular}


Ngai 2015 (Continued)

$\begin{aligned} & \text { Allocation concealment } \\ & \text { (selection bias) }\end{aligned} \quad$ Low risk
Quete: "The randomization allocation was concealed in identical, opaque, se-
quentially numbered, sealed envelopes".
(selection bias)

Low risk

Blinding of participants and personnel (performance bias)

All outcomes
Blinding was not described. but it is likely that participants and personnel could identify different interventions. It was unlikely that this lack of blinding could have caused different treatments between groups.

\section{Blinding of outcome as- High risk sessment (detection bias)} All outcomes

Incomplete outcome data Low risk
(attrition bias)

(attrition bias) quentially numbered, sealed envelopes".

No blinding stated, but it is possible that this lack of blinding could account for the different treatment effects between groups, because surgical site infection involves subjective assessment.

Postrandomisation exclusions were reported in the study due to protocol breach or loss to follow-up: PA group 8/463 (1.7\%), CA group 18/474 (3.8\%), and BOTH group $11 / 467$ (2.4\%). It is unlikely that this number of missing participants was enough to affect the outcome of surgical site infection.

Selective reporting (re- Low risk The same outcomes reported in the trial registry. porting bias)

Other bias Low risk Other bias was not noticed during review.

Pello 1990

\begin{tabular}{ll}
\hline Methods & Open comparative randomised trial \\
\hline Participants & Women with male fetus undergoing caesarean section. \\
& The trial was conducted in Paris, France. \\
\hline Interventions & $\begin{array}{l}\text { Skin preparation with chlorhexidine } 0.5 \% \text { was compared with } 70 \% \text { alcohol plus drape (IOBAN 2). A total } \\
\text { of } 22 \text { women were randomised, but the number allocated to each group was not stated. }\end{array}$ \\
\hline Outcomes & $\begin{array}{l}\text { Newborn exposure to iodine, measured from cord blood iodine concentration, 48-hour urine iodine ex- } \\
\text { cretion, and thyroid stimulating hormone blood concentration on the 5th day. }\end{array}$ \\
\hline Notes & Only abstract available \\
Type of anaesthesia not described \\
Trial dates: not reported \\
Sources of trial funding: not reported \\
Trialist declarations of interest: not reported
\end{tabular}

\section{Risk of bias}

\begin{tabular}{lll}
\hline Bias & Authors' judgement & Support for judgement \\
\hline $\begin{array}{l}\text { Random sequence genera- } \\
\text { tion (selection bias) }\end{array}$ & Unclear risk & Quote: "Twenty-two women had the skin preparation randomly allocated...". \\
\hline $\begin{array}{l}\text { Allocation concealment } \\
\text { (selection bias) }\end{array}$ & Unclear risk & No allocation concealment stated \\
\hline
\end{tabular}


Pello 1990 (Continued)
Blinding of participants
Unclear risk
No blinding stated and personnel (performance bias)

All outcomes

\begin{tabular}{lll}
\hline $\begin{array}{l}\text { Blinding of outcome as- } \\
\text { sessment (detection bias) } \\
\text { All outcomes }\end{array}$ & Low risk & No blinding stated. Evaluation of outcome was diagnosed by objective signs. \\
\hline $\begin{array}{l}\text { Incomplete outcome data } \\
\text { (attrition bias) }\end{array}$ & Unclear risk & Number of women in each group not reported \\
\hline $\begin{array}{l}\text { Selective reporting (re- } \\
\text { porting bias) }\end{array}$ & Unclear risk & $\begin{array}{l}\text { Only abstract available, so we did not know the originally planned outcomes. } \\
\text { The key outcome for this review was not reported (i.e. surgical site infection) } \\
\text { by this study, however the abstract made it clear that the study examined the } \\
\text { effect of iodine on newborns, so the lack of data reporting on women was not } \\
\text { deemed to be of concern. }\end{array}$ \\
\hline
\end{tabular}

Other bias Unclear risk There was too little information provided to exclude other bias.

\section{Springel 2017}

\begin{tabular}{|c|c|}
\hline Methods & Open-label, parallel-design, unmasked randomised controlled trial \\
\hline \multirow[t]{3}{*}{ Participants } & $\begin{array}{l}\text { All women undergoing caesarean section, who met eligibility criteria: caesarean delivery, age } 18 \text { to } 65 \\
\text { years, and ability to consent in English or Spanish }\end{array}$ \\
\hline & $\begin{array}{l}\text { Exclusion criteria were: inability or unwillingness to consent to study participation in English or Span- } \\
\text { ish, current incarceration, pre-operative diagnosis of chorioamnionitis, perceived inability to complete } \\
\text { follow-up for data collection, or any prior known allergy or adverse reaction to either study preparation }\end{array}$ \\
\hline & $\begin{array}{l}\text { The trial was conducted in an urban tertiary care institution (MetroHealth Medical Center, Cleveland, } \\
\mathrm{OH} \text { ), United States }\end{array}$ \\
\hline
\end{tabular}

Interventions
$\begin{aligned} & 932 \text { women were randomly assigned to either chlorhexidine-isopropyl alcohol }(\mathrm{CA} \text { group, } \mathrm{N}=461) \text { or } \\ & \text { povidone-iodine scrub and paint (PI group, } \mathrm{N}=471) \text {. Both interventions were applied to the skin pre- } \\ & \text { operatively for surgical site anti-sepsis. }\end{aligned}$
operatively for surgical site anti-sepsis.

\section{Outcomes}

Surgical site infection (composite SSI) occurring within 30 days, endometritis, re-admission to hospital for management of SSI, non-SSI wound complications

Definition of surgical site infection: > 1 of superficial, deep, and organ space (endometritis in the case of caesarean delivery) infection as defined by the US National Healthcare Safety Network (NHSN) of the CDC

General anaesthesia for some women
ClinicalTrials.gov Identifier: NCT02202577
Trial dates: February 2013 to May 2016
Sources of trial funding: Edward Henry Springel, MD
Trialist declarations of interest: reported, no conflict of interest

\section{Risk of bias}


Springel 2017 (Continued)

\begin{tabular}{|c|c|c|}
\hline Bias & Authors' judgement & Support for judgement \\
\hline \multirow{2}{*}{$\begin{array}{l}\text { Random sequence genera- } \\
\text { tion (selection bias) }\end{array}$} & Unclear risk & Quote: "... subjects were ... randomized ..." \\
\hline & & Comment: random sequence generation was not described \\
\hline $\begin{array}{l}\text { Allocation concealment } \\
\text { (selection bias) }\end{array}$ & Unclear risk & Allocation concealment was not described. \\
\hline \multirow{3}{*}{$\begin{array}{l}\text { Blinding of participants } \\
\text { and personnel (perfor- } \\
\text { mance bias) } \\
\text { All outcomes }\end{array}$} & Low risk & Quote: "Masking: none (open-label)". \\
\hline & & Comment: blinding of participants and personnel was not done, but it is un- \\
\hline & & $\begin{array}{l}\text { likely that this lack of blinding could have led to different treatments between } \\
\text { groups. }\end{array}$ \\
\hline \multirow{2}{*}{$\begin{array}{l}\text { Blinding of outcome as- } \\
\text { sessment (detection bias) } \\
\text { All outcomes }\end{array}$} & High risk & Quote: "Masking: none (open-label)". \\
\hline & & $\begin{array}{l}\text { Blinding of outcome assessment was not done, and it was possible that this } \\
\text { lack of blinding could account for the different treatment effects between } \\
\text { groups, because assessment of surgical site infection involved subjective as- } \\
\text { sessment. }\end{array}$ \\
\hline \multirow[t]{2}{*}{$\begin{array}{l}\text { Incomplete outcome data } \\
\text { (attrition bias) }\end{array}$} & Low risk & $\begin{array}{l}\text { Quote: "Rates of follow-up for evaluation after } 30 \text { days were } 97 \% \text { in the CA } \\
\text { group and } 96 \% \text { in the PI group". }\end{array}$ \\
\hline & & $\begin{array}{l}\text { Comment: the loss to follow-up was balanced between the } 2 \text { intervention } \\
\text { groups }\end{array}$ \\
\hline $\begin{array}{l}\text { Selective reporting (re- } \\
\text { porting bias) }\end{array}$ & Low risk & The same outcomes reported in the trial registry. \\
\hline Other bias & Low risk & Other bias was not noticed during review. \\
\hline
\end{tabular}

Tuuli 2016

\begin{tabular}{ll}
\hline Methods & Single-center, randomised, controlled trial \\
\hline Participants & $\begin{array}{l}\text { This study recruited pregnant women undergoing scheduled or unscheduled caesarean delivery at } \\
\text { Washington University Medical Center in St. Louis, United States. } \\
\text { Women who had known allergy to chlorhexidine, alcohol, iodine, or shellfish, or who had a skin infec- } \\
\text { tion adjacent to the operative site were excluded. }\end{array}$
\end{tabular}

Interventions

1147 women were randomly assigned to receive preoperative skin preparation with either chlorhexidine-alcohol ( $N=572$ women) or iodine-alcohol ( $N=575)$. Chlorhexidine-alcohol combination contained $2 \%$ chlorhexidine gluconate with $70 \%$ isopropyl alcohol, and iodine-alcohol combination contained $8.3 \%$ povidone-iodine with $72.5 \%$ isopropyl alcohol.

\section{Outcomes}

Primary outcome: superficial or deep surgical site infection within 30 days after caesarean delivery

Prespecified secondary outcomes: length of hospital stay, physician office visits and hospital readmissions for infection-related complications, endometritis, positive wound culture, skin irritation, and allergic reaction

Posthoc secondary outcomes: other wound complications (including skin separation, seroma, hematoma, and cellulitis), emergency department visits for wound complications, additional wound surgery, use of home health services or services of a wound clinic, and duration of wound care 
Tuuli 2016 (Continued)

Definition of surgical site infection: on the basis of the National Healthcare Safety Network definitions of the Centers for Disease Control and Prevention (CDC)

\section{Notes}

Women also received standard infection-prevention measures, including body weight-based preoperative antibiotic prophylaxis.

Type of anaesthesia not described

ClinicalTrials.gov Identifier: NCT01472549

Trial dates: September 2011 to June 2015

Sources of trial funding: supported by a Women's Reproductive Health Research Career Development grant from the Eunice Kennedy Shriver National Institute of Child Health and Human Development of the National Institutes of Health (1K12HD063086-01, to Drs Tuuli and Macones), and the Department of Obstetrics and Gynecology, Washington University School of Medicine in St. Louis

Trialist declarations of interest: reported. Dr Tuuli reported grant support from the National Institutes of Health during the conduct of the study. All other authors declared no conflict of interest.

\section{Risk of bias}

\begin{tabular}{|c|c|c|}
\hline Bias & Authors' judgement & Support for judgement \\
\hline $\begin{array}{l}\text { Random sequence genera- } \\
\text { tion (selection bias) }\end{array}$ & Low risk & $\begin{array}{l}\text { Quote "... computer-generated random sequence produced by the study sta- } \\
\text { tistician". }\end{array}$ \\
\hline $\begin{array}{l}\text { Allocation concealment } \\
\text { (selection bias) }\end{array}$ & Unclear risk & Not described \\
\hline $\begin{array}{l}\text { Blinding of participants } \\
\text { and personnel (perfor- } \\
\text { mance bias) } \\
\text { All outcomes }\end{array}$ & Low risk & $\begin{array}{l}\text { No blinding of participants and personnel, but it is unlikely that this lack of } \\
\text { blinding could have caused different treatments between groups. }\end{array}$ \\
\hline $\begin{array}{l}\text { Blinding of outcome as- } \\
\text { sessment (detection bias) } \\
\text { All outcomes }\end{array}$ & Low risk & $\begin{array}{l}\text { Quote: "The diagnosis of surgical-site infection within } 30 \text { days after cesarean } \\
\text { delivery "... was made by the treating physician and verified by means of chart } \\
\text { review by the principal investigator, who was unaware of the study-group as- } \\
\text { signments". }\end{array}$ \\
\hline \multirow[t]{2}{*}{$\begin{array}{l}\text { Incomplete outcome data } \\
\text { (attrition bias) }\end{array}$} & Low risk & $\begin{array}{l}\text { Quote: "A similar number of participants in each group - } 34(5.9 \%) \text { in the } \\
\text { chlorhexidine-alcohol group and } 31(5.4 \%) \text { in the iodine-alcohol group - } \\
\text { were lost to follow-up". }\end{array}$ \\
\hline & & $\begin{array}{l}\text { Comment: reason for loss to follow-up were 'did not have postoperative fol- } \\
\text { low-up' or 'discontinued study'. Numbers in each group, and for each reason, } \\
\text { were similar between the } 2 \text { interventions. }\end{array}$ \\
\hline $\begin{array}{l}\text { Selective reporting (re- } \\
\text { porting bias) }\end{array}$ & High risk & $\begin{array}{l}\text { Compared to the trial registration, more outcomes were reported in the final } \\
\text { report, and some predefined outcomes, such as proportion of women with } \\
\text { skin contamination after skin prep or cost savings were not reported. }\end{array}$ \\
\hline Other bias & Low risk & Other bias was not noticed during review. \\
\hline
\end{tabular}

Ward 2001

Methods Randomisation using a table of random numbers


Ward 2001 (Continued)
Participants
All women undergoing caesarean section
The trial was conducted at Livingston Hospital, Eastern Province of South Africa.

Interventions $\begin{aligned} & \text { All women }(\mathrm{N}=605) \text { were prepared before the incision by washing the abdomen and perineum with } 4 \% \\ & \text { chlorhexidine soap. On the operating table, the abdomen was swabbed with } 0.5 \% \text { chlorhexidine in } 80 \% \\ & \text { alcohol solution for } 30 \text { seconds. After the preparation: }\end{aligned}$

the experimental group $(\mathrm{N}=305)$ received incisional plastic drape;

the control group $(\mathrm{N}=300)$ did not receive a drape.

\section{Outcomes}

Surgical site infection and length of hospital stay

Definition of surgical site infection: diagnosed if 2 of 3 features were present: (1) erythematous cellulitis, (2) seropurulent discharge from the wound, (3) positive swab culture (organisms and leucocytes).

Notes

All women received preoperative antibiotics administration of $1 \mathrm{~g}$ cephazolin intravenously, unless antibiotics were already being administered. In addition, a $1 \mathrm{~g}$ metronidazole suppository was inserted preoperatively, and repeated after 12 hours.

Women received general anaesthesia

Trial dates: August 1992 to January 1993

Sources of trial funding: not reported

Trialist declarations of interest: not reported

\section{Risk of bias}

\begin{tabular}{lll}
\hline Bias & Authors' judgement & Support for judgement \\
\hline $\begin{array}{l}\text { Random sequence genera- } \\
\text { tion (selection bias) }\end{array}$ & Low risk & Quote: "...taken from a random number table". \\
\hline $\begin{array}{l}\text { Allocation concealment } \\
\text { (selection bias) }\end{array}$ & Low risk & $\begin{array}{l}\text { Quote: "On deciding that a woman was to undergo caesarean section, the } \\
\text { surgeon removed an opaque unmarked envelope from a box of identical en- } \\
\text { velopes. Inside was a card, inscribed with an integer taken from a random } \\
\text { number table. If the number was even, a drape was to be used and if odd, then } \\
\text { no drape was used. The card was then resealed in the envelope and stapled to } \\
\text { the patient's folder, and opened only when she left the study". }\end{array}$ \\
\hline
\end{tabular}

\begin{tabular}{|c|c|c|}
\hline $\begin{array}{l}\text { Blinding of participants } \\
\text { and personnel (perfor- } \\
\text { mance bias) }\end{array}$ & Low risk & $\begin{array}{l}\text { Quote: "...patients received general anesthesia as part of normal hospital prac- } \\
\text { tice and the drape was applied after induction and removed before extuba- } \\
\text { tion". }\end{array}$ \\
\hline
\end{tabular}

Alloutcomes

Comment: although not explicitly stated in the study, we assumed that the medical personnel were not blinded, as they could see the different interventions. It was unlikely that this lack of blinding could have caused different caesarean treatment relevant to the outcomes.

\begin{tabular}{lll}
\hline $\begin{array}{l}\text { Blinding of outcome as- } \\
\text { sessment (detection bias) } \\
\text { All outcomes }\end{array}$ & Low risk & $\begin{array}{l}\text { Quote: "Assessor bias was avoided because postoperative care was conducted } \\
\text { by staff unrelated to surgery". }\end{array}$ \\
\hline $\begin{array}{l}\text { Incomplete outcome data } \\
\text { (attrition bias) }\end{array}$ & Low risk & $\begin{array}{l}\text { Postrandomisation exclusions were reported in the study, } 15(2.4 \%) \text { in total } \\
\text { were excluded due to critical data missing, } 2 \text { additional women from the con- } \\
\text { trol group were excluded: } 1 \text { due to ruptured appendix and another who re- } \\
\text { quested early discharge on day } 2 \text { after caesarean section. Based on a sensi- }\end{array}$
\end{tabular}


Ward 2001 (Continued)

tivity analysis, it was unlikely that this number of missing participants was enough to affect the outcome of surgical site infection.

\begin{tabular}{lll}
\hline $\begin{array}{l}\text { Selective reporting (re- } \\
\text { porting bias) }\end{array}$ & Unclear risk & $\begin{array}{l}\text { Selective reporting was not noticed during review, but we were unable to con- } \\
\text { sult the trial registry. }\end{array}$ \\
\hline Other bias & Low risk & Other bias was not noticed during review. \\
\hline
\end{tabular}

Characteristics of excluded studies [ordered by study ID]

\begin{tabular}{|c|c|}
\hline Study & Reason for exclusion \\
\hline Brown 1984 & $\begin{array}{l}\text { Trial compared antiseptics for general surgery that included cases of caesarean section, but the tri- } \\
\text { al did not report separate results for the caesarean section cases. }\end{array}$ \\
\hline Kosus 2010 & Intervention was different. Rifamycin is an antibiotic, not an antiseptic agent. \\
\hline NCT01700803 & Intervention was different. This study focused on preoperative handwashing by the surgical team. \\
\hline NCT02027324 & Intervention was different. This study focused on preoperative handwashing by the surgical team. \\
\hline Nili 2015 & This is not an RCT but a cohort study. \\
\hline Robins 2005 & $\begin{array}{l}\text { Trial compared the effectiveness of chlorhexidine spray and single-use sachets for skin preparation } \\
\text { before regional nerve blockade, not for preparation of the incision site before caesarean section. }\end{array}$ \\
\hline
\end{tabular}

Characteristics of ongoing studies [ordered by study ID]

\section{NCT00528008}

\begin{tabular}{ll}
\hline Trial name or title & $\begin{array}{l}\text { A comparison of surgical preparations and surgical site infection rates for elective caesarean sec- } \\
\text { tions }\end{array}$ \\
\hline Methods & Randomised controlled study \\
\hline Participants & Pregnant women at term, over 19 years old, who booked elective caesarean section \\
\hline Interventions & Comparator A = povidone iodine \\
& Comparator B = chlorhexidine gluconate \\
\hline Outcomes & Primary outcome; the rate of surgical site infection \\
& $\begin{array}{l}\text { Secondary outcomes (within } 6 \text { weeks of caesarean section operation): readmission to hospital, ex- } \\
\text { tended length of admission, need for intravenous antibiotics, need for repeat procedure, such as } \\
\text { drainage, increased outpatient surveillance }\end{array}$ \\
\hline Starting date & December 2007 \\
\hline Contact information & PI: Dr Paula Mallaley, Obstetrics and Gybnecology, Memorial University of Newfoundland \\
\hline Notes & NCT Number; NCT00528008 \\
\hline
\end{tabular}


NCT01870583

\begin{tabular}{ll}
\hline Trial name or title & Comparison of surgical skin preparations during caesarean deliveries \\
\hline Methods & Prospective randomised observational study \\
\hline Participants & Women undergoing non-emergency indication for caesarean at term \\
\hline Interventions & lodine povidone versus chlorhexidine versus combination iodine and chlorhexidine \\
\hline Outcomes & $\begin{array}{l}\text { Primary outcome: caesarean surgical site infection (42 days after delivery); surgical site infection } \\
\text { will follow CDC guidelines }\end{array}$ \\
\hline Starting date & February 2013 \\
\hline Contact information & Dr David J Garry, Montefiore Medical Center \\
\hline Notes & NCT Number; NCT01870583
\end{tabular}

\section{NCT02396329}

Trial name or title

Chlorhexidine versus povidone-iodine antisepsis for reduction of post caesarean section surgical site infection

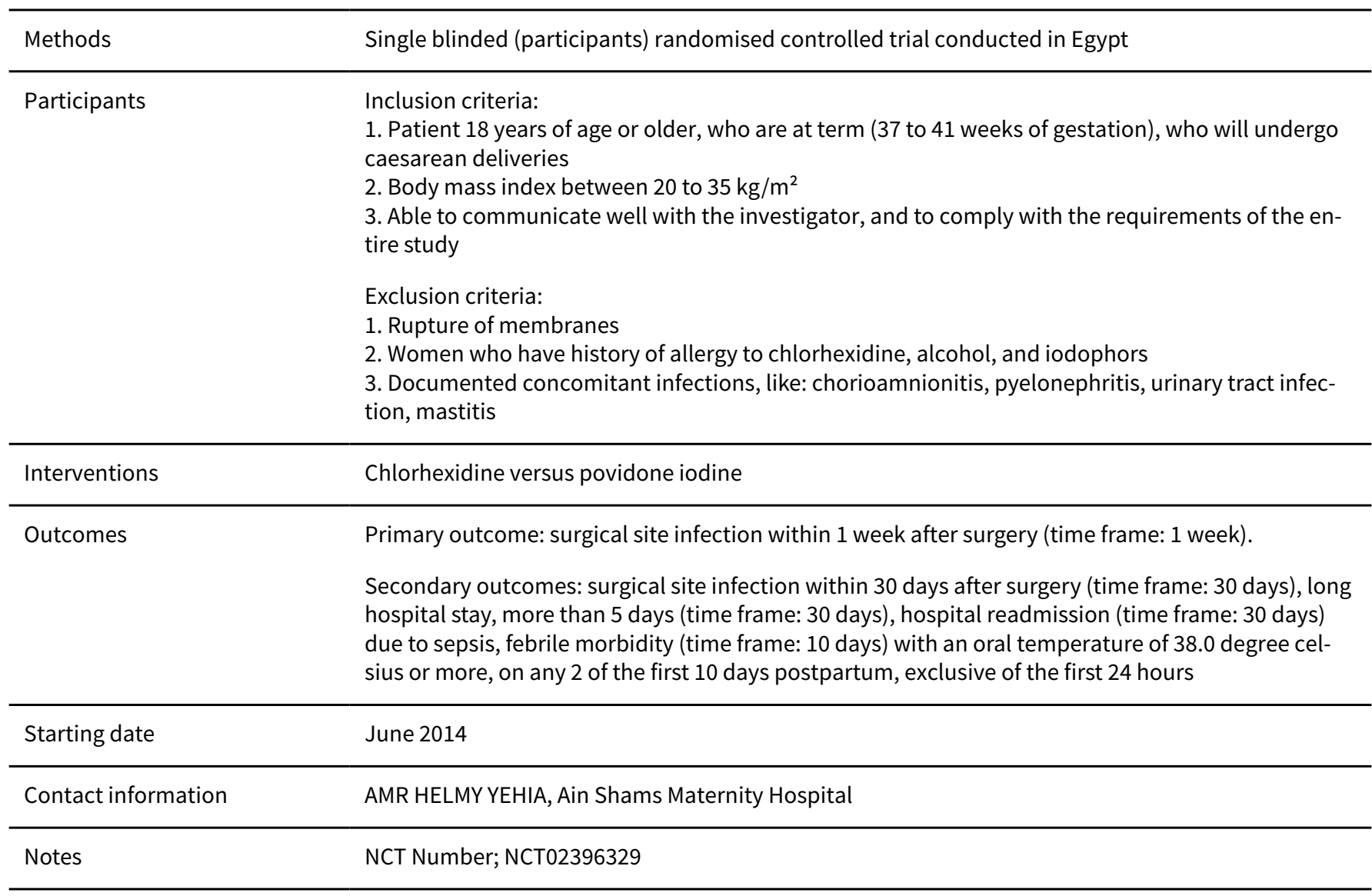


NCT02402907

\begin{tabular}{|c|c|}
\hline Trial name or title & STRIPES Study: Study To Reduce Infection Post caEsarean Section \\
\hline Methods & Masked randomised controlled trial conducted in the United States \\
\hline \multirow[t]{2}{*}{ Participants } & $\begin{array}{l}\text { Women ( } 18 \text { years or older) }>24 \text { weeks' gestation, scheduled for a primary or repeat caesarean sec- } \\
\text { tion. }\end{array}$ \\
\hline & Exclusion criteria: allergy to chlorhexidine, unplanned or emergency caesarean section \\
\hline Interventions & $2 \%$ chlorhexidine gluconate cloth versus placebo cloth \\
\hline \multirow[t]{2}{*}{ Outcomes } & Primary outcomes: rate of infectious morbidity (time frame: up to 6 weeks) \\
\hline & $\begin{array}{l}\text { Secondary outcomes: incidence of neonatal intensive care unit admissions (time frame: up to } 6 \\
\text { weeks), maternal length of stay (time frame: up to } 6 \text { weeks), incidence of maternal readmissions } \\
\text { (time frame: up to } 6 \text { weeks) }\end{array}$ \\
\hline Starting date & April 2015 \\
\hline Contact information & Contact: Brittany Noel Robles, MD \\
\hline Notes & NCT Number; NCT02402907 \\
\hline
\end{tabular}

CDC: Centers for Disease Control and Prevention

DATA AND ANALYSES

Comparison 1. Drape versus no drape

\begin{tabular}{lllll}
\hline Outcome or subgroup title & $\begin{array}{l}\text { No. of } \\
\text { studies }\end{array}$ & $\begin{array}{l}\text { No. of } \\
\text { partici- } \\
\text { pants }\end{array}$ & Statistical method & Effect size \\
\hline 1 Surgical site infection & 2 & 1294 & Risk Ratio (M-H, Fixed, 95\% Cl) & $1.29[0.97,1.71]$ \\
\hline 1.1 lodine & 1 & 691 & Risk Ratio (M-H, Fixed, 95\% Cl) & $1.42[0.98,2.04]$ \\
\hline 1.2 Chlorhexidine & 1 & 603 & Risk Ratio (M-H, Fixed, 95\% Cl) & $1.11[0.70,1.76]$ \\
\hline 2 Length of stay & 1 & 603 & Mean Difference (IV, Fixed, 95\% Cl) & $0.10[-0.27,0.46]$ \\
\hline
\end{tabular}

Analysis 1.1. Comparison 1 Drape versus no drape, Outcome 1 Surgical site infection.

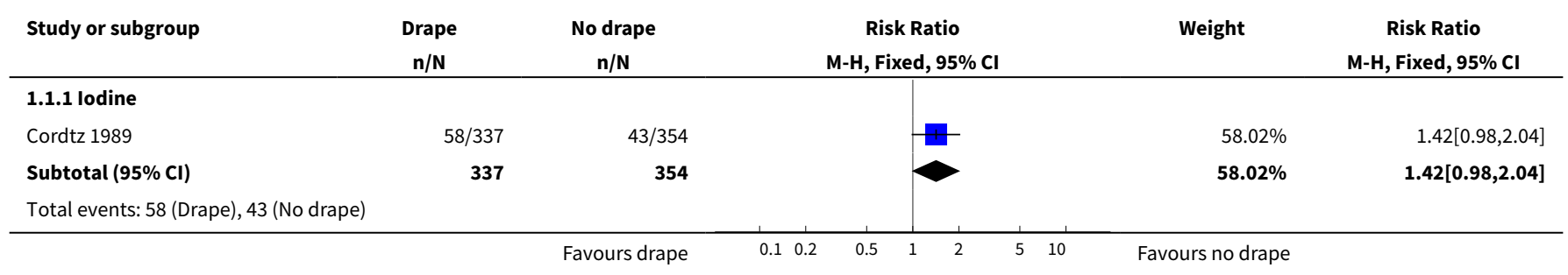




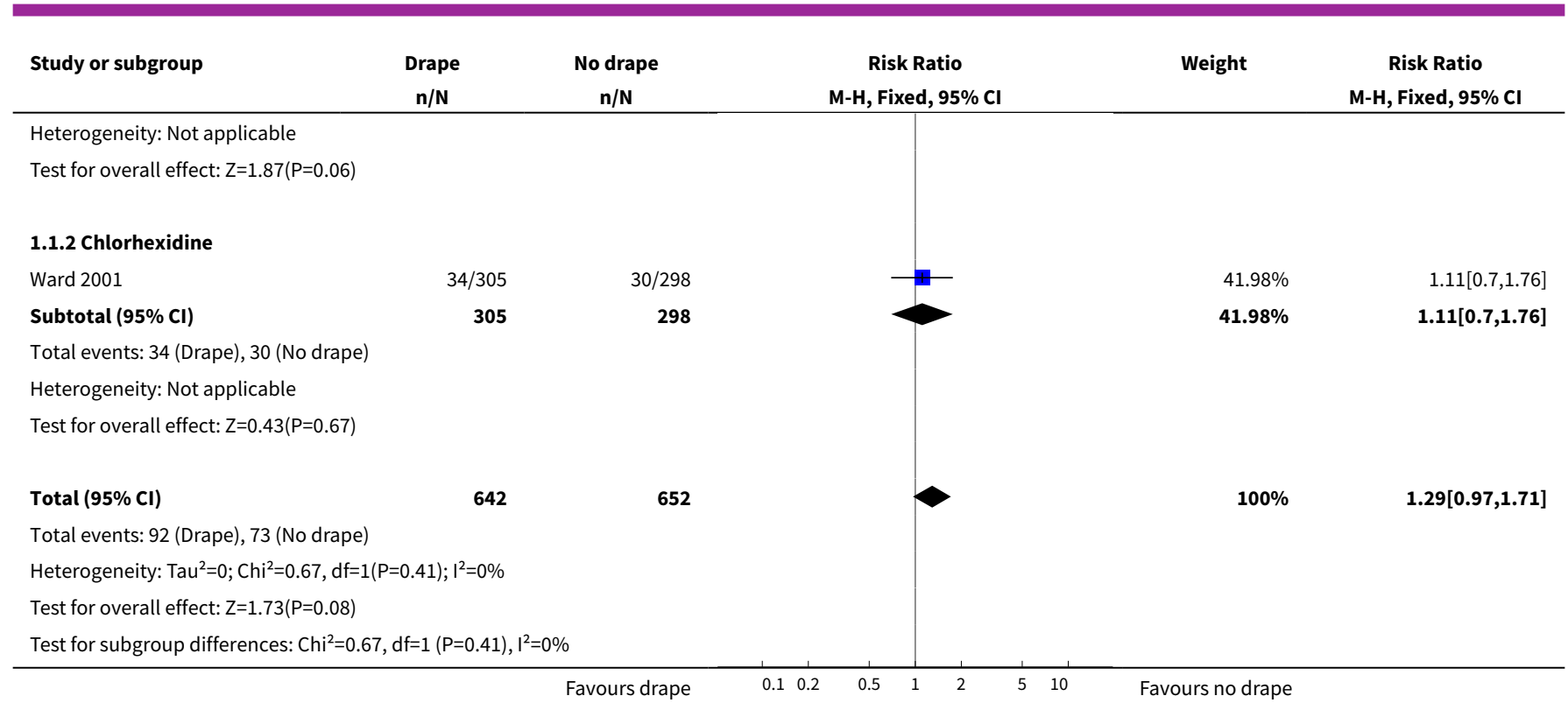

Analysis 1.2. Comparison 1 Drape versus no drape, Outcome 2 Length of stay.

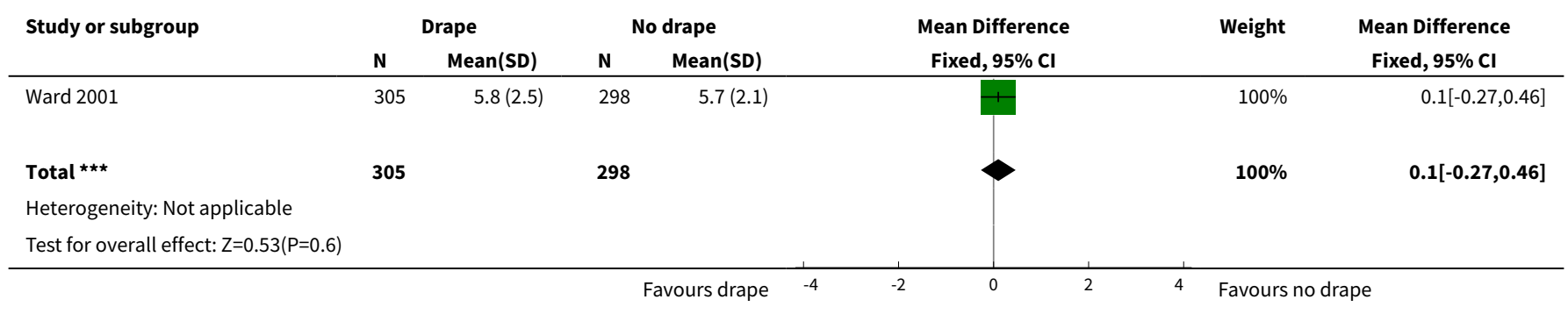

\section{Comparison 2. One-minute alcohol scrub with iodophor drape versus five-minute iodophor scrub without drape}

\begin{tabular}{llllll}
\hline Outcome or subgroup title & $\begin{array}{l}\text { No. of } \\
\text { studies }\end{array}$ & $\begin{array}{l}\text { No. of } \\
\text { partici- } \\
\text { pants }\end{array}$ & Statistical method & Effect size \\
\hline 1 Surgical site infection & 1 & 79 & Risk Ratio (M-H, Fixed, 95\% Cl) & $0.0[0.0,0.0]$ \\
\hline 2 Endomyometritis & 1 & 79 & Risk Ratio (M-H, Fixed, 95\% Cl) & $1.62[0.29,9.16]$ \\
\hline $\begin{array}{l}\text { 3 Reduction of skin bacteria colony } \\
\text { counts }\end{array}$ & 1 & 79 & Mean Difference (IV, Fixed, 95\% Cl) & $0.07[-0.34,0.48]$ \\
\hline
\end{tabular}


Analysis 2.1. Comparison 2 One-minute alcohol scrub with iodophor drape versus

five-minute iodophor scrub without drape, Outcome 1 Surgical site infection.

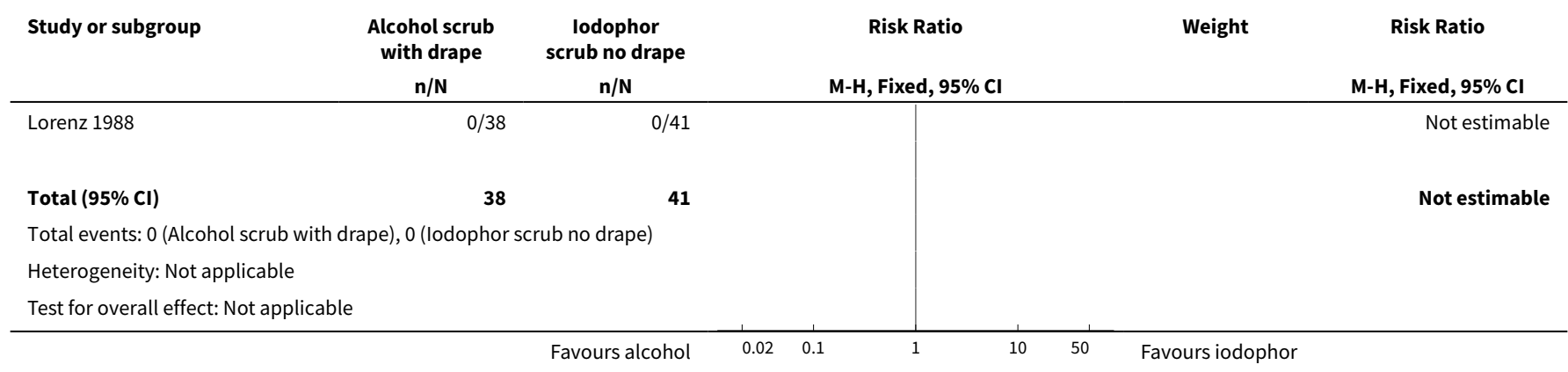

Analysis 2.2. Comparison 2 One-minute alcohol scrub with iodophor drape versus five-minute iodophor scrub without drape, Outcome 2 Endomyometritis.

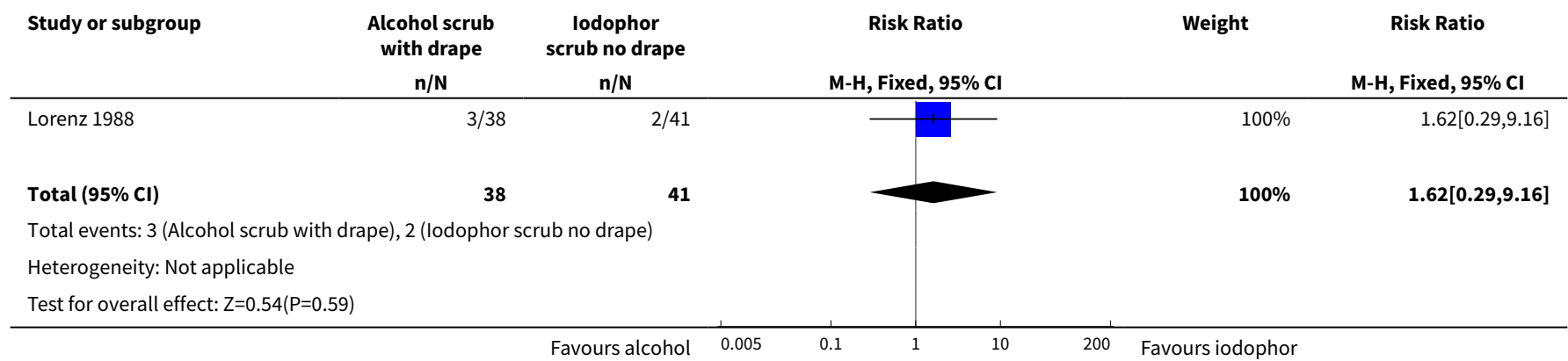

Analysis 2.3. Comparison 2 One-minute alcohol scrub with iodophor drape versus fiveminute iodophor scrub without drape, Outcome 3 Reduction of skin bacteria colony counts.

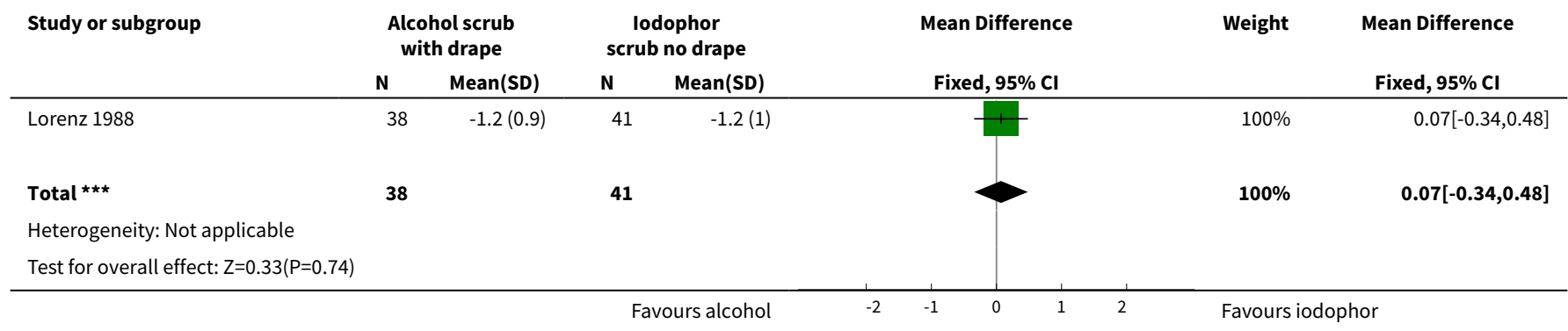

\section{Comparison 3. Parachlorometaxylenol with iodine versus iodine alone}

\begin{tabular}{lllll}
\hline Outcome or subgroup title & $\begin{array}{l}\text { No. of } \\
\text { studies }\end{array}$ & $\begin{array}{l}\text { No. of } \\
\text { partici- } \\
\text { pants }\end{array}$ & Statistical method & Effect size \\
\hline 1 Surgical site infection & 1 & 50 & Risk Ratio (M-H, Fixed, 95\% Cl) & $0.33[0.04,2.99]$ \\
\hline
\end{tabular}




\begin{tabular}{lllll}
\hline Outcome or subgroup title & $\begin{array}{l}\text { No. of } \\
\text { studies }\end{array}$ & $\begin{array}{l}\text { No. of } \\
\text { partici- } \\
\text { pants }\end{array}$ & Statistical method & Effect size \\
\hline 2 Endometritis & 1 & 50 & Risk Ratio (M-H, Fixed, 95\% Cl) & $0.88[0.56,1.38]$ \\
\hline
\end{tabular}

Analysis 3.1. Comparison 3 Parachlorometaxylenol with iodine versus iodine alone, Outcome 1 Surgical site infection.

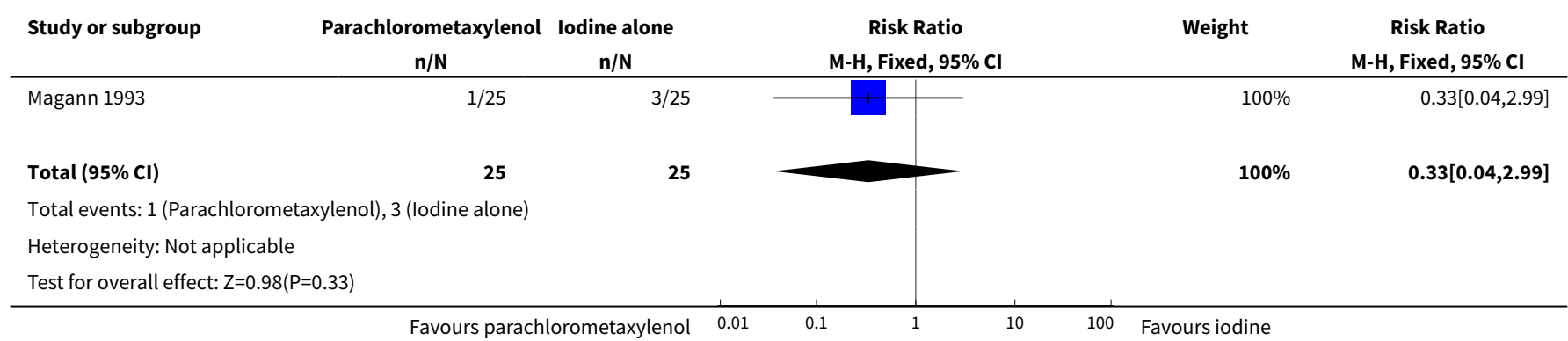

\section{Analysis 3.2. Comparison 3 Parachlorometaxylenol with iodine versus iodine alone, Outcome 2 Endometritis.}

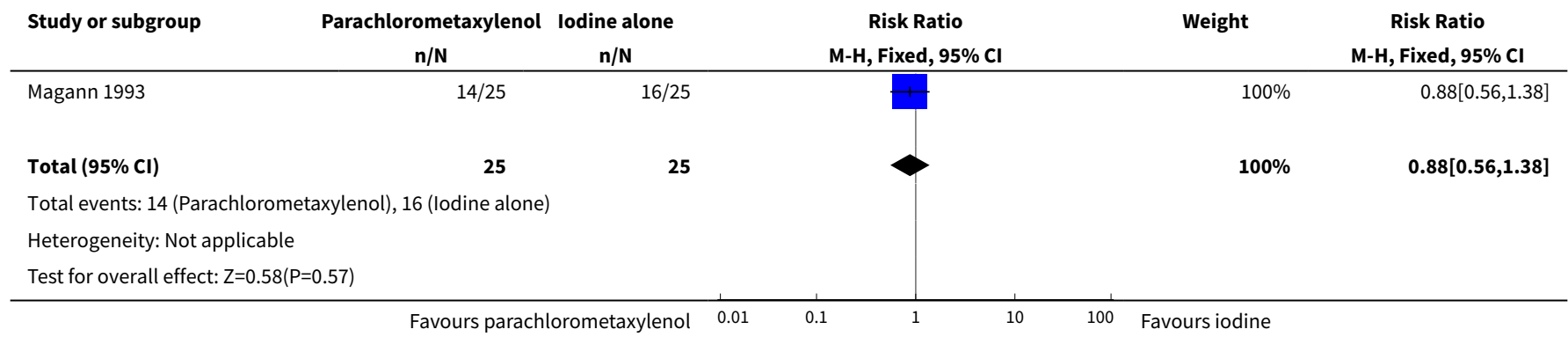

\section{Comparison 4. Chlorhexidine gluconate versus povidone iodine}

\begin{tabular}{lllll}
\hline Outcome or subgroup title & $\begin{array}{l}\text { No. of } \\
\text { studies }\end{array}$ & $\begin{array}{l}\text { No. of } \\
\text { partici- } \\
\text { pants }\end{array}$ & Statistical method & Effect size \\
\hline 1 Surgical site infection & 6 & 3607 & Risk Ratio (M-H, Fixed, 95\% Cl) & $0.80[0.62,1.02]$ \\
\hline 2 Endometritis & 2 & 2079 & Risk Ratio (M-H, Fixed, 95\% Cl) & $1.01[0.51,2.01]$ \\
\hline 3 Re-admission resulting from infection & 2 & 2079 & Risk Ratio (M-H, Fixed, 95\% Cl) & $0.71[0.43,1.19]$ \\
\hline 4 Bacterial growth 18 hours & 1 & 60 & Risk Ratio (M-H, Fixed, 95\% Cl) & $0.23[0.07,0.70]$ \\
\hline 5 Adverse events (maternal) & 2 & & Risk Ratio (M-H, Fixed, 95\% Cl) & Subtotals only \\
\hline 5.1 Any skin reaction & 1 & 374 & Risk Ratio (M-H, Fixed, 95\% Cl) & $0.79[0.32,1.96]$ \\
\hline
\end{tabular}




\begin{tabular}{llllll}
\hline Outcome or subgroup title & $\begin{array}{l}\text { No. of } \\
\text { studies }\end{array}$ & $\begin{array}{l}\text { No. of } \\
\text { partici- } \\
\text { pants }\end{array}$ & Statistical method & Effect size \\
\hline 5.2 Erythema & 2 & 1521 & Risk Ratio (M-H, Fixed, 95\% Cl) & $1.13[0.57,2.26]$ \\
\hline 5.3 Skin irritation or allergic skin reaction & 2 & 1521 & Risk Ratio (M-H, Fixed, 95\% Cl) & $0.60[0.22,1.63]$ \\
\hline
\end{tabular}

Analysis 4.1. Comparison 4 Chlorhexidine gluconate versus povidone iodine, Outcome 1 Surgical site infection.

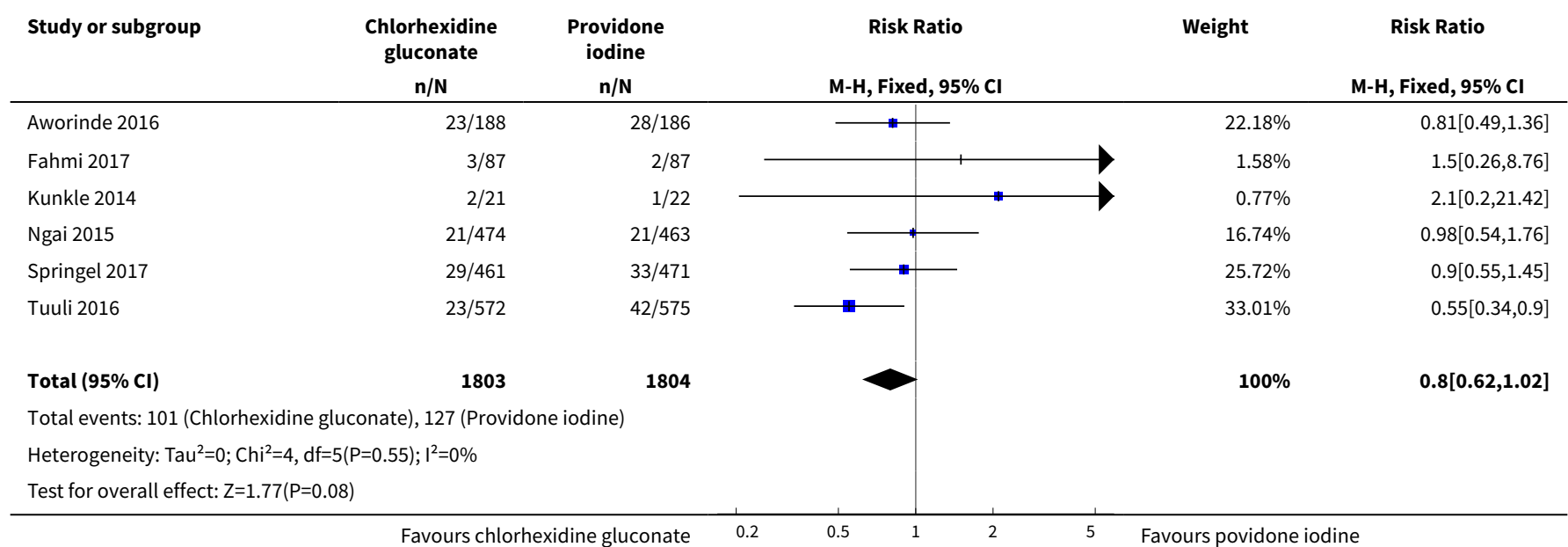

Analysis 4.2. Comparison 4 Chlorhexidine gluconate versus povidone iodine, Outcome 2 Endometritis.

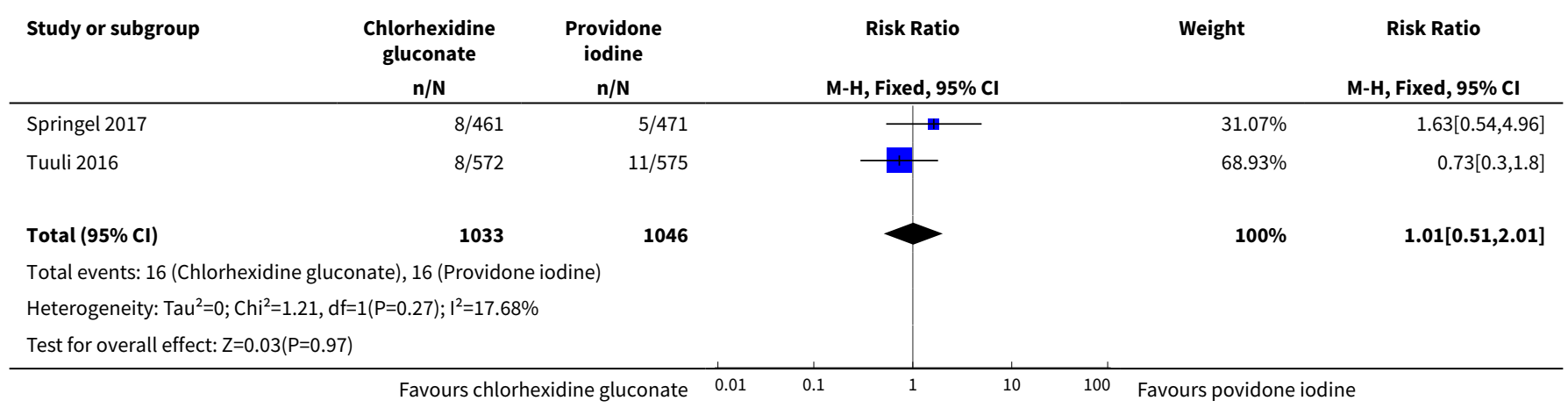

Analysis 4.3. Comparison 4 Chlorhexidine gluconate versus povidone iodine, Outcome 3 Re-admission resulting from infection.

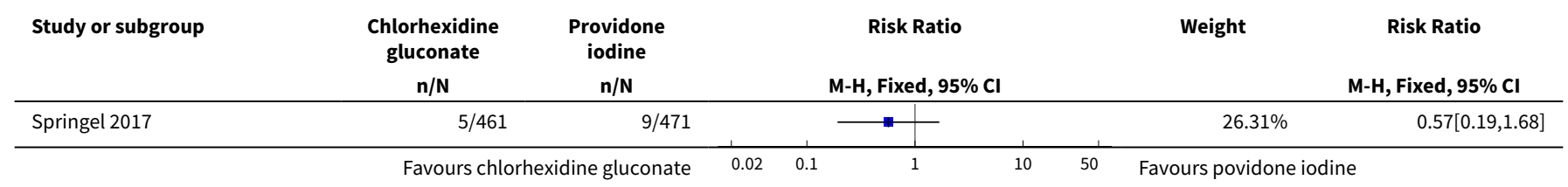




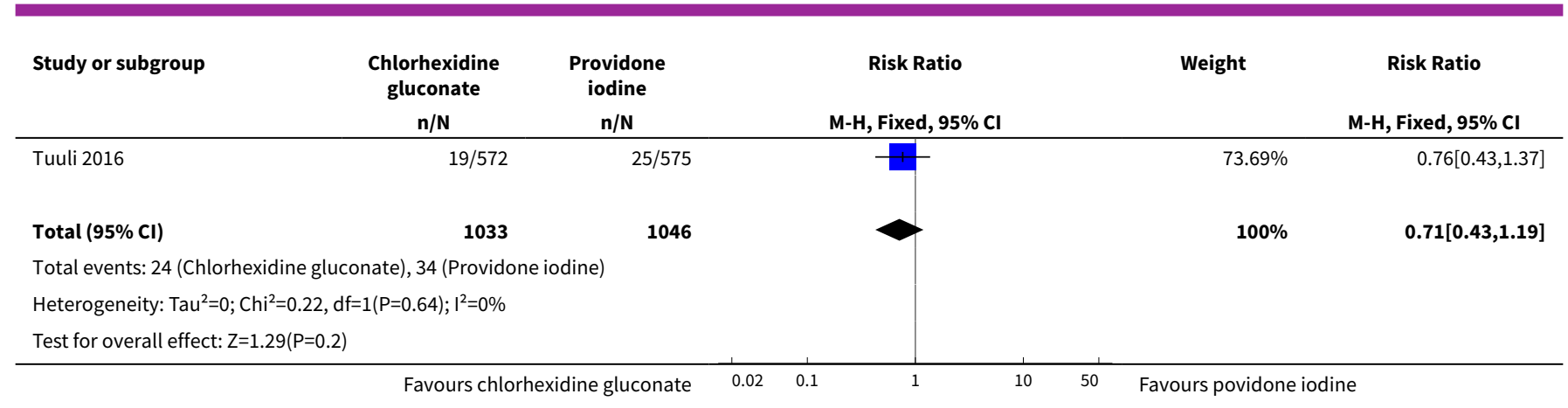

Analysis 4.4. Comparison 4 Chlorhexidine gluconate versus povidone iodine, Outcome 4 Bacterial growth 18 hours.

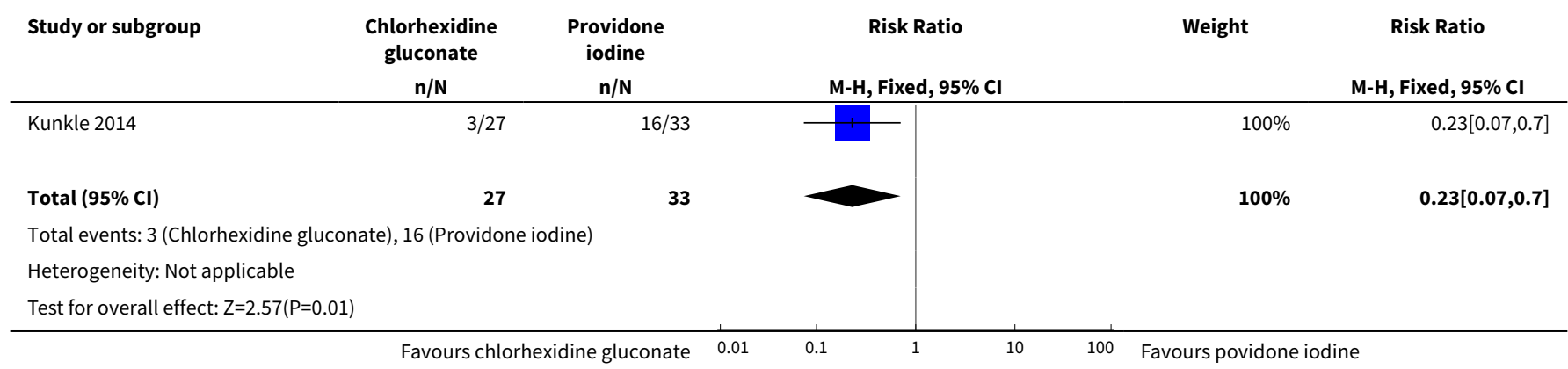

Analysis 4.5. Comparison 4 Chlorhexidine gluconate versus povidone iodine, Outcome 5 Adverse events (maternal).

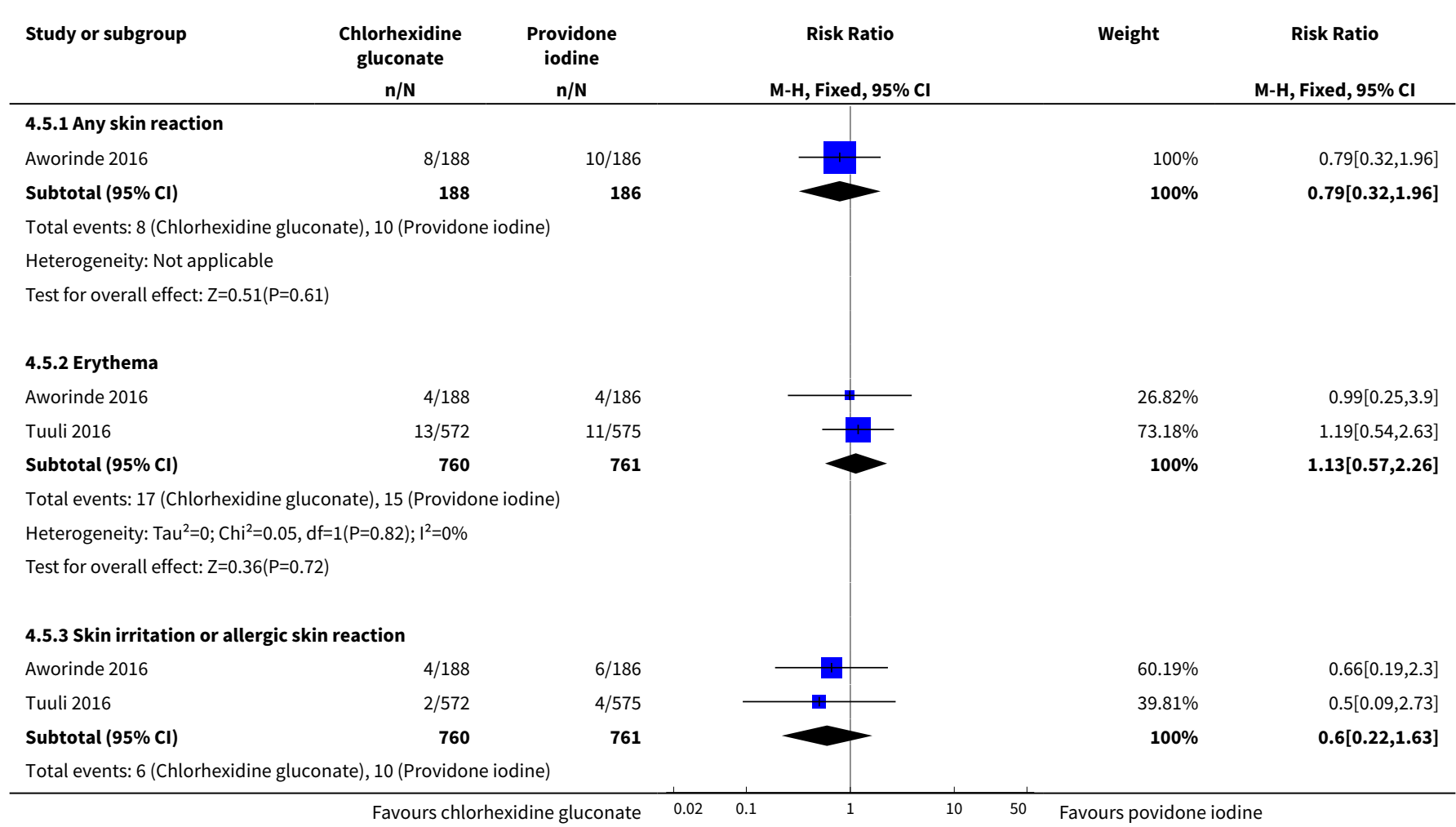




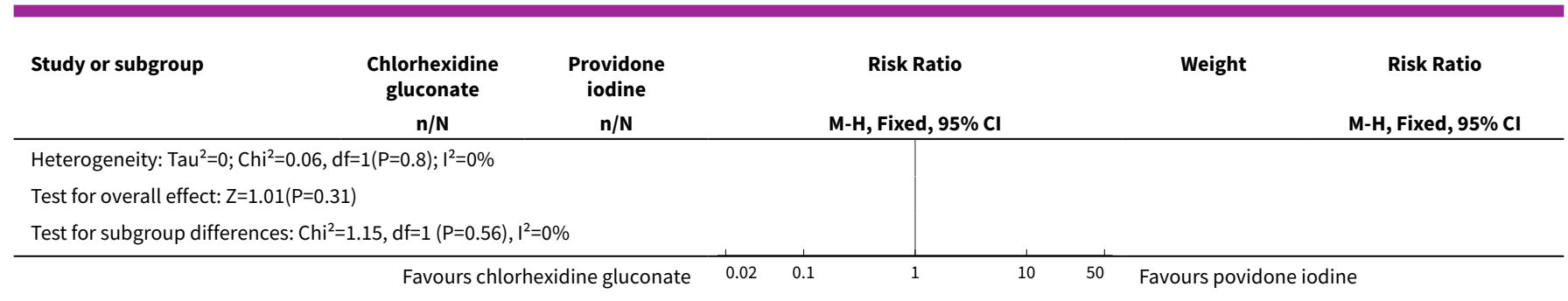

\section{AP PEN DICES}

\section{Appendix 1. Search methods for ClinicalTrials.gov and ICTRP}

\section{ClinicalTrials.gov}

Advanced search

Type of study: Interventional

Condition/disease: Infection; Cesarean Section

Intervention: lodine; Chlorhexidine; Anti-infective

Type of study: Interventional

Condition/disease: Cesarean Section Complications

Other terms: skin preparation; antiseptics; skin cleansing

\section{ICTRP}

Each line was run separately

cesarean AND preparation

caesarean AND preparation

cesarean AND prep

caesarean AND prep

cesarean AND cleansing

caesarean AND cleansing

cesarean AND iodine

caesarean AND iodine

cesarean AND chlorhexidine

caesarean AND chlorhexidine

cesarean AND antiseptic(s)

caesarean AND and antiseptic(s)

\section{WHAT'S NEW}




\begin{tabular}{lll}
\hline Date & Event & Description \\
\hline 27 November 2017 & $\begin{array}{l}\text { New citation required but conclusions } \\
\text { have not changed }\end{array}$ & Conclusions have not been changed. \\
\hline 27 November 2017 & New search has been performed & $\begin{array}{l}\text { Search updated. We included five new studies (Aworinde 2016; } \\
\text { Fahmi 2017; Ngai 2015; Springel 2017; Tuuli 2016) (including } \\
\text { one previous ongoing trial: Tuuli 2016) and excluded one new } \\
\text { study (Nili 2015). We also identified two new ongoing trials } \\
\text { (NCT02402907; NCT02396329). }\end{array}$ \\
\hline
\end{tabular}

\section{HISTORY}

Protocol first published: Issue 4, 2008

Review first published: Issue 9, 2012

\begin{tabular}{lll}
\hline Date & Event & Description \\
\hline 26 June 2014 & $\begin{array}{l}\text { New citation required but conclusions } \\
\text { have not changed }\end{array}$ & The inclusion of one new trial did not change the conclusions. \\
\hline 26 June 2014 & New search has been performed & $\begin{array}{l}\text { Search updated: one new trial added (Kunkle 2014), three new } \\
\text { ongoing trials added and three new trials excluded. Methods up- } \\
\text { dated. 'Summary of findings' tables incorporated for this update. }\end{array}$ \\
\hline
\end{tabular}

\section{CONTRIBUTIONS OF AUTHORS}

Diah Hadiati wrote the first draft of the protocol. Detty Nurdiati and Hakimi Mohammad contributed to defining the selection criteria and commented on the draft. All authors contributed to data extraction, preparation of results, and finalisation of the report.

For the 2014 update, Erika Ota prepared the first draft, incorporated the results of the additional new study, and prepared the 'Summary of findings' tables. All authors approved the final version of the update for publication.

For the 2018 update, Diah Hadiati, Mohammad Hakimi, and Detty S Nurdiati incorporated results of additional new studies. Katharina da Silva Lopes extracted data and assessed risk of bias for newly added studies, incorporated the results of the additional studies, and prepared the manuscript. Erika Ota rechecked extracted data and risk of bias assessment, prepared the 'Summary of finding' tables, and edited the review text. All authors approved the final version of the update for publication.

\section{DECLARATIONSOF INTEREST}

Diah R Hadiati: Diah Hadiati is a named author on Fahmi 2017, but was not involved in the screening process and risk of bias assessment.

Mohammad Hakimi: none known

Detty S Nurdiati: none known

Erika Ota: none known

Katharina da Silva Lopes: none known

\section{SOURCES OF SUPPORT}

\section{Internal sources}

- Universitas Gadjah Mada, Indonesia.

- St.Luke's international university, Japan. 


\section{External sources}

- Wellcome Trust (SEA-ORCHID Project), UK.

- UNDP-UNFPA-UNICEF-WHO-World Bank Special Programme of Research, Development and Research Training in Human Reproduction (HRP), Department of Reproductive Health and Research (RHR), World Health Organization, Switzerland.

\section{DIFFERENCES BETWEEN PROTOCOL AND REVIEW}

The methods have been updated to reflect the latest Cochrane Handbook for Systematic Reviews of Interventions (Higgins 2011), and Cochrane Pregnancy and Childbirth's methodological guidelines. We added two secondary outcomes; reduction of skin bacteria colony counts and adverse effects. We used GRADE to assess the quality of the evidence and included 'Summary of findings' tables.

In the 2018 update, we added a co-author (Katharina da Silva Lopes). We also added a search of ClinicalTrials.gov and the WHO International Clinical Trials Registry Platform (ICTRP).

We also assessed the quality of the evidence for two new outcomes, using GRADE criteria.

1. Length of stay

2. Adverse events (maternal or neonatal)

We assessed the quality of, and added the two outcomes to the 'Summary of findings' table because length of stay indicates the severity of the infection, which prolongs the hospital stay after caesarean section, and adverse events are important outcomes for women's decision making.

In this update, we provided additional information about the included studies: trial dates, sources of trial funding, and trial authors' declarations of interest.

\section{INDEX TERMS}

\section{Medical Subject Headings (MeSH)}

Anti-Infective Agents, Local [ ${ }^{*}$ therapeutic use]; Bandages; Cesarean Section [ ${ }^{*}$ adverse effects]; Chlorhexidine [therapeutic use]; Endometritis [ ${ }^{*}$ prevention \& control]; Ethanol [therapeutic use]; lodine [therapeutic use]; lodophors [therapeutic use]; Length of Stay; Povidone-lodine [therapeutic use]; Preoperative Care [methods]; Randomized Controlled Trials as Topic; Surgical Drapes; Surgical Wound Infection [ ${ }^{\star}$ prevention \& control]; Xylenes [therapeutic use]

\section{MeSH check words}

Adult; Female; Humans; Pregnancy 